\title{
Gabbro-Eclogite Reaction Rate and Its Geophysical Significance
}

\author{
Thomas J. Ahrens \\ Seismological Laboratory. California Institute of Technology \\ Pasadena, California 91109

\section{Gerald SchuberT} \\ Department of Planetary and Space Science, University of California \\ Los Angeles, California 90024
}

\begin{abstract}
The gabbro-garnet granulite-eclogite transformation may play a significant role in driving the motions of terrestrial lithospheric plates. Whether or not this transformation is in fact important as a driving mechanism for plate tectonics depends on the relationship of the reaction time to geologic time. Solid state diffusion under completely dry conditions is investigated as a possible model for the gabbro-eclogite reaction, with the result that it could not produce the transition in geologically meaningful times at temperatures less than circa $600^{\circ}-800^{\circ} \mathrm{C}$ in the earth's upper mantle. Other reaction mechanisms must exist for the geologically rapid occurrence of the phase change at lower temperatures. It is found that one of these mechanisms can be grain interstitial diffusion in a mantle with minute amounts of water. In this model, dissolved ions migrate through water films surrounding mineral grains to sites of reaction. A water-undersaturated mantle contains a small quantity of hydrous phases, such as chlorite, amphibole, or talc, the presence of which implies that interstices within the rock can contain water in equilibrium with these minerals and at a pressure $\boldsymbol{P}_{\mathrm{H}_{2} \mathrm{O}}$ which is less than the pressure in the rock. Implicit then is the presence of other gases and/or structural rock integrity. This $\boldsymbol{P}_{\mathrm{H}_{2} \mathrm{O}}$ is calculated for serpentine, tremolite, and talc as a function of temperature and rock pressure. Various pertinent cations are sufficiently mobile in aqueous solution that at high temperature and high pressure, diffusion through water will not significantly slow the reaction. Rather, pressure-induced solubility of ions in this water vapor is the important ratelimiting process in the model. Rock pressure and temperature must be such as to generate at least $\sim 0.5-1$ kbar of $\boldsymbol{P}_{\mathrm{H}_{2}} \mathrm{O}$ in the presence of the hydrous phases for geologically short reaction times. Under ambient conditions $\boldsymbol{P}_{\mathrm{H}_{2} \mathrm{O}}$ is quite small, the cations are relatively insoluble, and the reaction time is geologically long. Upon subduction of a basaltic upper crust or lithosphere, for example, an increase in $\boldsymbol{P}_{\mathrm{H}_{2} \mathrm{O}}$ occurs, and with increasing pressure the mineral solubility in this supercritical water increases dramatically, yielding geologically short reaction times; for example, $\sim 20 \mathrm{~m}$.y. for chlorite-containing rocks with $\sim 10^{-\mathrm{s}} \mathrm{-cm}$ film thickness for ion diffusion at depths of $\sim 15-30 \mathrm{~km}$ and at temperatures of $\sim 150^{\circ}-300^{\circ} \mathrm{C}$ for different heating models of the descending slab. For gabbros in which amphibole (tremolite)-pyroxene equilibria buffer the partial pressure of water, depths of $\sim 55-70 \mathrm{~km}$ and temperatures of $400^{\circ}-550^{\circ} \mathrm{C}$ are required for rapid eclogitization, again for different slab heating models. Thus contrary to previous suggestions, the gabbro-eclogite transformation, as it probably occurs in the descending or spreading lithosphere, is not simply rate-controlled by temperature but depends heavily on pressure and on the nature of the minor hydrous minerals present.
\end{abstract}

\section{INTRODUCTION AND BACKGROUND}

It has been observed that with increasing pressure at high temperature $\left(\sim 800^{\circ}\right.$ to $\left.1200^{\circ} \mathrm{C}\right)$ a gabbroic mixture (pyroxene and plagioclase, with or without olivine, quartz, and spinel) with a density of $2.9-3.1 \mathrm{~g} / \mathrm{cm}^{3}$ reacts, starting at $10-15 \mathrm{kbar}$, and forms a garnet granulite (garnet, pyroxene, and plagioclase) with a density between 3.2 and $3.3 \mathrm{~g} / \mathrm{cm}^{3}$. At still higher pressure (15-30 kbar), depending on specific composition, an eclogite assemblage (garnet and pyroxene) with a density in the range $3.4-3.5 \mathrm{~g} / \mathrm{cm}^{3}$ forms.

There have been numerous speculations regarding the role of this gabbro-garnet granulite-eclogite phase transformation in a number of phenomena in the earth's interior. Ito and Kennedy [1971] and Kennedy and Ito [1972] on the basis of their claim of fairly sharp increases in density at the onsets of the gabbro-garnet granulite and garnet granulite-eclogite transitions have recently modified the original phase change interpretation of the Mohorovicic discontinuity [Lovering, 1958; Kennedy, 1959]. They suggest that the discontinuity in seismic $P$ wave velocity from 7.5 to $8.2 \mathrm{~km} / \mathrm{s}$ found at depths of about $50 \mathrm{~km}$ under continental areas which have undergone recent

Copyright (c) 1975 by the American Geophysical Union. vertical movement and at depths of about $20 \mathrm{~km}$ under certain ocean rises may represent the equilibrium phase boundary between garnet granulite and eclogite [Ito and Kennedy, 1970]. Also they propose that the shallower seismic $P$ wave velocity discontinuity of $6.5-7.5 \mathrm{~km} / \mathrm{s}$ may map a rate process boundary that is an approximate isotherm along which the temperature is sufficiently high $\left(\sim 400^{\circ} \mathrm{C}\right)$ that recrystallization of metastable gabbro to the stable garnet granulite occurs.

Ringwood and Green [1966] in spite of their objections to a worldwide gabbro-eclogite $\mathbf{M}$ discontinuity suggested that in areas of high heat flow and presumably of high temperatures at the base of the crust, as occur in tectonic provinces, the gabbro-eclogite transition could explain the often gradational Moho observed in these regions. They also speculated that piles of basalt and gabbro formed at continental margins in the initial stages of orogeny would subsequently transform to eclogite and sink into the underlying mantle, triggering the orogenic epic and eventually resulting in continental accretion. A second related hypothesis proposed by Ringwood and Green [1966] (see also Schubert and Turcotte [1972]) is that gabbro in the oceanic crust undergoes thermally activated transformation to eclogite upon descending into the mantle at an island arc subduction zone. The gravitational body force associated with this relatively cool and dense eclogitic layer provides all 
or part of the driving mechanism for the mantle flow field associated with plate tectonics. The gabbro-eclogite transformation then takes place in the upper $\sim 300 \mathrm{~km}$ of the subduction zone. At greater depths the downward body forces accompanying the lower transition of $\alpha-(\mathrm{Mg}, \mathrm{Fe})_{2} \mathrm{SiO}_{4}$ to the $\beta$ and $\gamma$ phase have recently been described by Turcotte and Schubert [1971].

Press [1969] has suggested that as the basalts and gabbros which may be produced at depth under midocean ridges move laterally away from the ridge, carried by the horizontal motion of the lithosphere below, transformation to eclogite could occur upon cooling. The resulting gravitationally unstable lithosphere would then readily sink at an island arc subduction zone. This idea calls for the gabbro-eclogite transformation to occur during cooling at relatively constant pressure, whereas the Ringwood and Green [1966] and Schubert and Turcotte [1972] suggestion, although similar in some respects, envisions the phase change taking place upon heating with increasing pressure. A further significant distinction between the Press [1969] and Ringwood and Green [1966] and Schubert and Turcotte [1972] mechanisms is that the former invokes an eclogite suboceanic lithosphere, while the latter refer only to the gabbro-eclogite phase change in the oceanic crust known to be of basaltic composition. We emphasize that the phase change densification of only the subducting oceanic crust, should it occur at sufficiently shallow depth in the mantle, could provide a downward body force in the lithosphere comparable to that of thermal contraction of the entire descending lithosphere or to that associated with the elevation of the olivine-spinel phase boundary [Turcotte and Schubert, 1971].

Proper evaluation of these proposals requires knowledge of the pressure-temperature stability field of the transformation, its rate of reaction, and either the nature of the variations in the geotherm or the heating or cooling rates of material elements. Extensive experimental investigations have delineated the equilibrium stability field of the phase change at relatively high temperatures and pressures [e.g., Boyd and England, 1959; Yoder and Tilley, 1962; Ringwood and Green, 1966; Green and Ringwood, 1967; Cohen et al., 1967; Ito and Kennedy, 1970, 1971; Green and Ringwood, 1972; Kennedy and Ito, 1972], and although extrapolation of the experimental data to lower temperatures and pressures is still a controversial issue [Green and Ringwood, 1972; Kennedy and Ito, 1972], our knowledge of the equilibrium stability field is adequate for evaluation of the role of the reaction in many geophysical processes. However, the same cannot be said of our knowledge of the reaction rate; aside from approximate estimates of the reaction times at two temperatures in a single experiment [Ito and Kennedy, 1971], no data on the reaction rate are available. Unfortunately, our lack of knowledge of reaction rates is the most serious limiting factor in our assessment of the importance of the gabbro-eclogite transformation in many phenomena.

As an example, consider the gabbro-eclogite transformation in the descending crust. According to the pressure-temperature stability diagram of Figure 1 and the shear stress heating curves for crustal elements [Turcotte and Schubert, 1973] (shown in Figure 9, for example), a layer of crustal basalt and gabbro attached to the upper surface of a lithospheric slab descending into the mantle will find itself in the stability field of eclogite at relatively shallow depth (notwithstanding the controversy over the extrapolation of the empirically determined stability fields to low temperature and pressure, this

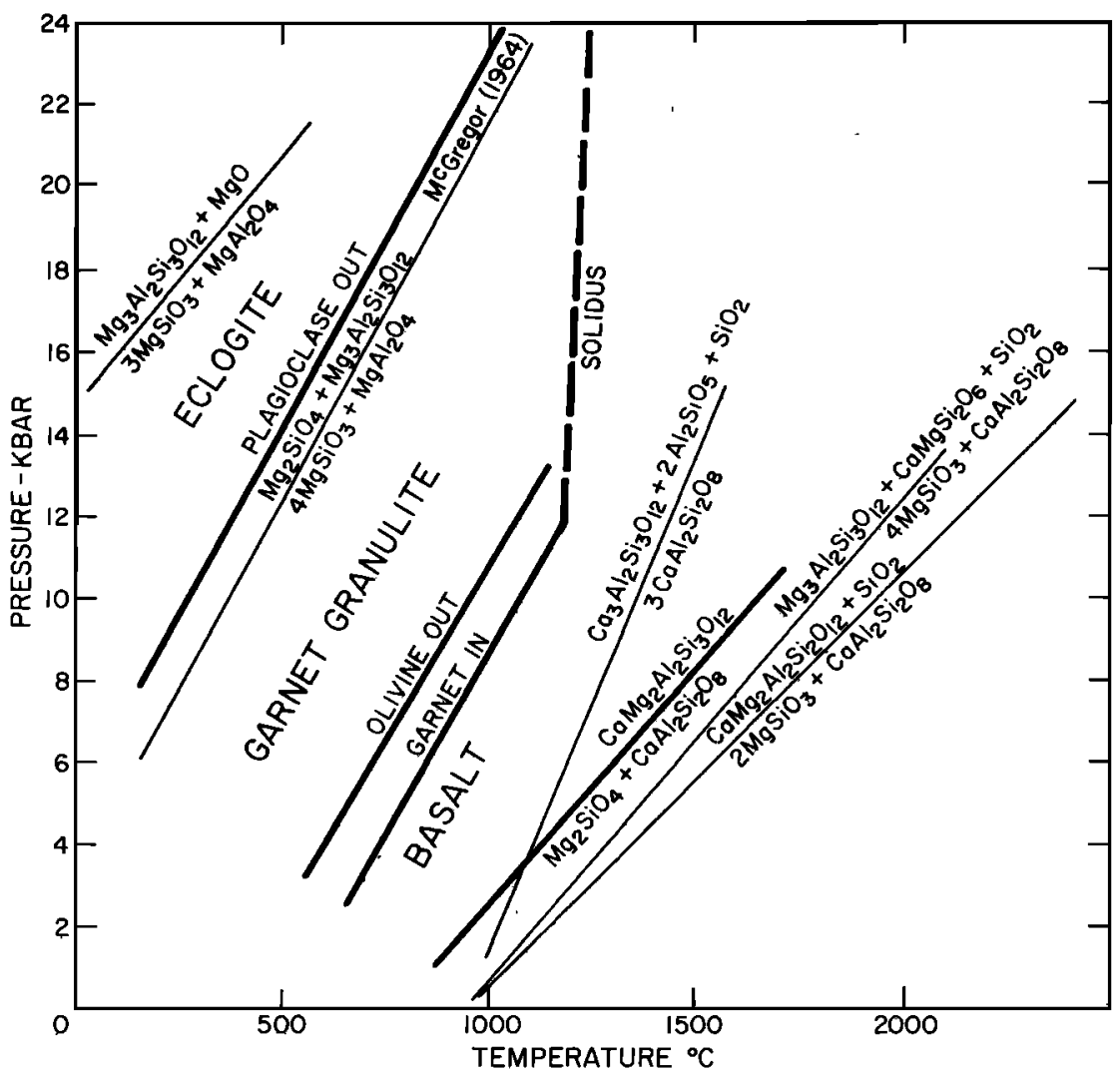

Fig. 1. Theoretical phase lines for garnet-forming reactions in Mg-rich pyroxene and olivine determined from thermochemical data of Robie and Waldbaum [1968] and Ahrens [1973]. Also shown is the experimentally determined phase line of the reaction enstatite + spinel $=$ forsterite + pyrope [McGregor, 1964] together with the approximate range of the gabbro-garnet granulite-eclogite phase change. 
depth will certainly be no more than 20-30 km). However, at these shallow depths the temperature of crustal elements will be less than about $200^{\circ} \mathrm{C}$ [Turcotte and Schubert, 1973], and the rate of reaction may be sufficiently slow for the gabbro to be metastable well into the eclogite stability field. The transition from gabbro to eclogite in the relatively cold descending crust is a rate-dominated process. The equilibrium phase diagram tells us only that the reaction may occur in the descending crust; rate processes determine whether or not the reaction will in fact take place.

In the present paper we hope to clarify the importance of the gabbro-eclogite transition to several processes in the earth's interior by better understanding the reaction rate of the transformation. This is accomplished by developing simplified microscopic models of the phase change which permit assessments of reaction times and their dependences on variables such as pressure, temperature, and grain size. Two basic models will be considered, one a solid state diffusion model for the transition under totally dry conditions and the other a model of diffusion through interstitial water vapor. The major conclusion we reach is that the transformation may occur via grain interstitial diffusion of ionic species if the gabbro-eclogite reaction is to occur on a geologically significant time scale at temperatures below $\sim 800^{\circ} \mathrm{C}$. The reaction rate, instead of being controlled by temperature as was commonly believed (recall the Ringwood and Green [1966] and Schubert and Turcotte [1972] proposal for thermally activated transformation in the descending crust, for example) is governed mainly by the generation of water vapor in equilibrium with hydrous mineral phases and the increase in ion solubility with pressure in the supercritical water.

\section{Case for Solid State Diffusion}

In examining the possible physical mechanisms which control the gabbro-eclogite transformation under dry conditions, solid state diffusion is a prime candidate since it is known to be experimentally difficult to form garnet granulite, or eclogite, at temperatures lower than about $800^{\circ} \mathrm{C}$ [Ito and Kennedy, 1971]. However, even at these temperatures with $\mathrm{Li}_{2} \mathrm{~B}_{4} \mathrm{O}_{7}$ as a fluxing agent, complete transformation in very fine grained starting materials was not achieved on a 1-week time scale. Ito and Kennedy [1971] reported that at $1200^{\circ} \mathrm{C}$ equilibrium was 'attained in approximately $5 \mathrm{~min}$. From these data and the assumption that the reaction time is proportional to the exponential of the product of a constant and the reciprocal temperature (see (8)), they inferred that in geologic times of $10^{8}-10^{7} \mathrm{yr}$, recrystallization of gabbro to garnet granulite, or eclogite, should occur down to temperatures as low as about $400^{\circ} \mathrm{C}$. At still lower temperatures, gabbro was inferred to remain metastable in the garnet granulite, or eclogite, fields for extremely long periods.

The solid state diffusion model of the gabbro-eclogite reaction considers the growth of garnet at the interface between crystals of olivine and plagioclase with the rate of reaction controlled by the diffusion of cations through the growing garnet crystal. Geologic examples of solid diffusion limited mineral formation may be provided by certain of the coronas or reaction rims in high-temperature metamorphic rocks. In the formation of certain of these metamorphic textures, coarse-grained anhydrous mineral assemblages in cooling from high temperature undergo reactions at grain boundaries resulting in the growth of new minerals which armor the primary ones and thus slow the diffusion-controlled reactions.

A classic multilayered corona which occurs at the junction of olivine and plagioclase in gabbroic rocks is described by Spry [1969] as follows. The successive rims in the compound corona are olivine-hypersthene-hornblende-garnetplagioclase. The end members olivine and plagioclase apparently reacted under anhydrous metamorphic conditions to produce hypersthene and garnet, which were in part later transformed under hydrous conditions to hornblende. Figure 2 [from Spry, 1969] shows the approximate compositions of the successive rims in this complex layered corona. The mineral composition of each rim represents the chemical gradient formed by the migration of $\mathrm{Fe}^{++}$and $\mathrm{Mg}^{++}$outward from olivine and $\mathrm{Ca}^{++}$and $\mathrm{Al}^{+3}$ outward from plagioclase. An example of a complex corona texture between olivine and plagioclase is shown in Figure 3 [from Spry, 1969].

We shall attempt by considering only one reaction to examine the diffusion processes in systems which realistically represent the more crucial of the 19 or so reactions which Green and Ringwood [1967] list as occurring in gábbros of various initial compositions upon transforming to eclogite. The reaction, which is most amenable to a simple analysis, is

$$
\begin{aligned}
(\mathrm{Mg}, \mathrm{Fe})_{2} \mathrm{SiO}_{4}(\text { olivine }) & +\mathrm{CaAl}_{2} \mathrm{Si}_{3} \mathrm{O}_{8}(\text { anorthite }) \\
& \rightarrow\left(\mathrm{Mg}, \mathrm{Fe}_{2} \mathrm{CaAl}_{2} \mathrm{Si}_{4} \mathrm{O}_{12}\right. \text { (garnet) }
\end{aligned}
$$

The theoretical phase lines for this reaction (assuming only the $\mathrm{Mg}$ end member) and other garnet-forming reactions for $\mathrm{Mg}$ rich pyroxene and olivine together with the approximate range of the gabbro-eclogite phase change are shown in Figure 1. Thermochemical data selected from Robie and Waldbaum [1968] and Ahrens [1973] were used in the calculations. A point on the theoretical phase equilibrium line was found by iteratively determining values of temperature and pressure at which the free energies of the phases were identical. This point, together with the Clausius-Clapeyron relation, determines the theoretical phase line.

The simplicity of reaction (1) follows from the fact that it involves only three species, each having the same $\mathrm{Si} / \mathrm{O}$ ratio. We assume that although the $\mathrm{SiO}_{4}=$ tetrahedra are rearranged in reaction (1), they undergo no net transport. This assumption seems well justified, as recent data for $\mathrm{O}^{-}$self-diffusion in forsterite [Heuer et al., 1973] demonstrate very low diffusivities $\left(10^{-15}-10^{-14} \mathrm{~cm}^{2} / \mathrm{s}\right.$ at $\left.1400^{\circ}-1500^{\circ} \mathrm{C}\right)$. Thus we assume that under dry conditions diffusion of such cations as $\mathrm{Ca}^{++}, \mathrm{Al}^{+3}$,

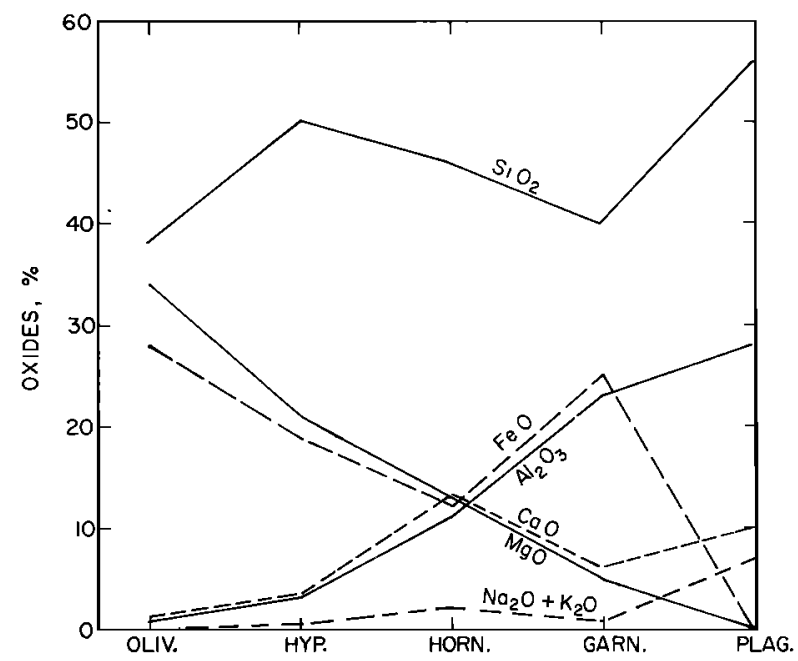

Fig. 2. Variation in composition of minerals in successive layers of a compound corona texture; from inside to outside: olivine, hypersthene, hornblende, garnet, and plagioclase [from Spry, 1969] 


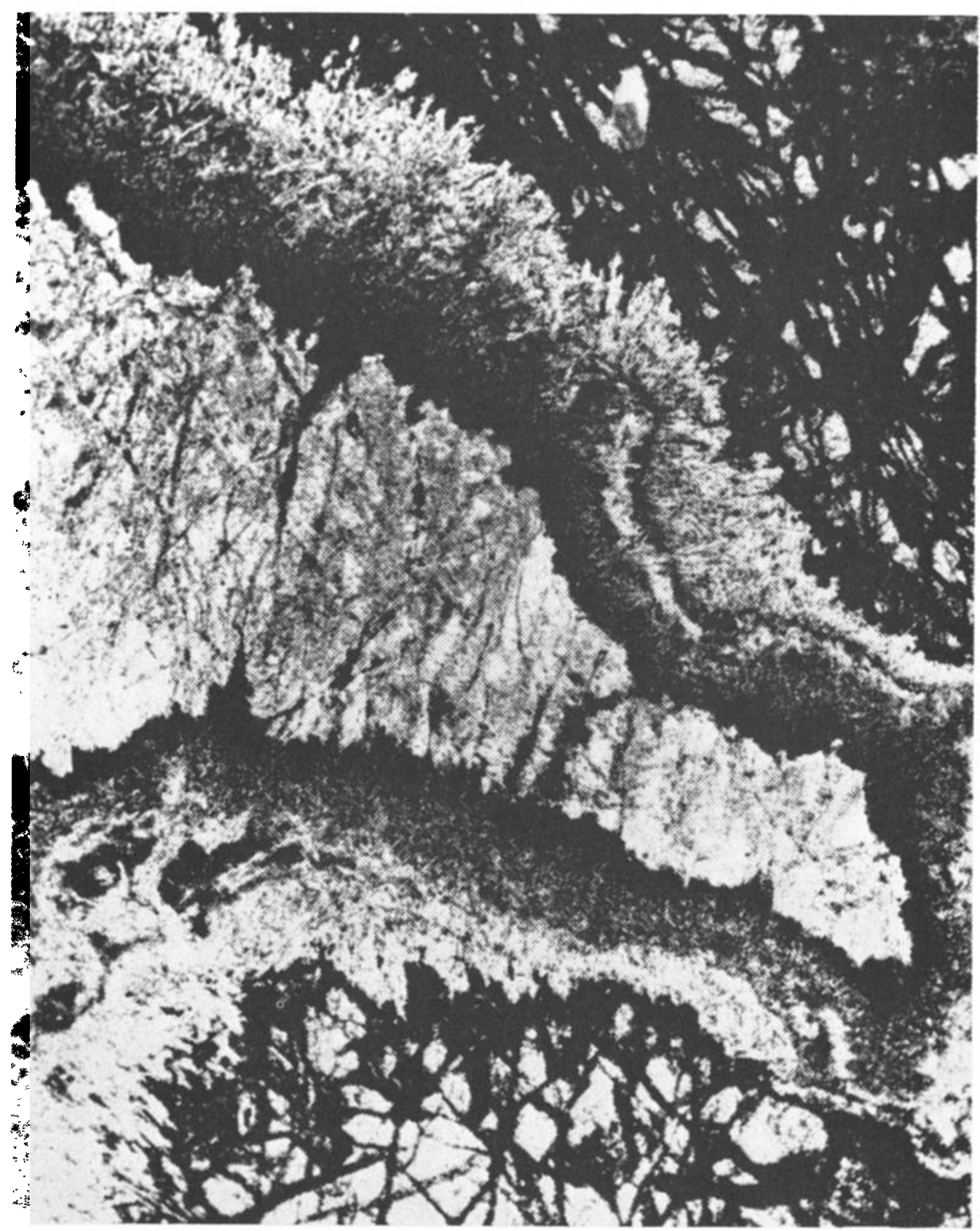

Fig. 3. Microphotograph of complex corona texture between olivine (center) and plagioclase (outside) of the type: depicted in Figure 1 [from Spry, 1969].

$\mathrm{Mg}^{++}$, and $\mathrm{Fe}^{++}$will occur as suggested in Figure 4. Note, as in Figure 2, that the garnet forms between the olivine and plagioclase. Similar solid state diffusion-controlled reactions, which occur in the formation of spinels from the oxides, have been treated in detail by Schmalzreid [1969]. Other similar diffusion-controlled reactions have been studied for the growth of $\mathrm{SrAl}_{2} \mathrm{O}_{4}$ and $\mathrm{BaAl}_{2} \mathrm{O}_{4}$ (spinels) by Iseki et al. [1970], for $\mathrm{BiFeO}_{3}$ (a perovskite) by Mukherjee and Wang [1970], for $\mathrm{Al}_{2} \mathrm{SiO}_{5}$ (mullite) by Davis and Park [1972], and for $\mathrm{CaZrO}_{3}$ by Augers et al. [1972] all via solid state reaction from the oxides. For reaction (1), charge balance considerations at the interfaces imply that two moles of garnet form at the garnetanorthite interface for each mole of garnet forming at the forsterite-garnet interface.

To relate diffusion constants to reaction rates, we have assumed that cation diffusion through a growing garnet crystal will limit its growth rate, because, of the three species participating in reaction (1), garnet is the densest and because, since garnet is forming in situ, it is likely to be relatively free from deformation-induced defects (and hence present a high. impedance for diffusive transport). If $F$ is the number of reaction-limiting cations diffusing across a growing garnet crystal per unit area per second, i.e., cation flux, then

$$
F \propto D C / x
$$

where $C$ is the number concentration of this ion in the species in which it originates, $x$ is the thickness of the growing garnet crystal, and $D$ is the coefficient of diffusion of this ion in garnet. Proportionality (2) assumes that the excess concentration of the reaction-limiting ion is linearly distributed over the garnet phase and that this concentration gradient drives the diffusion process. This assumption cannot be completely valid since 

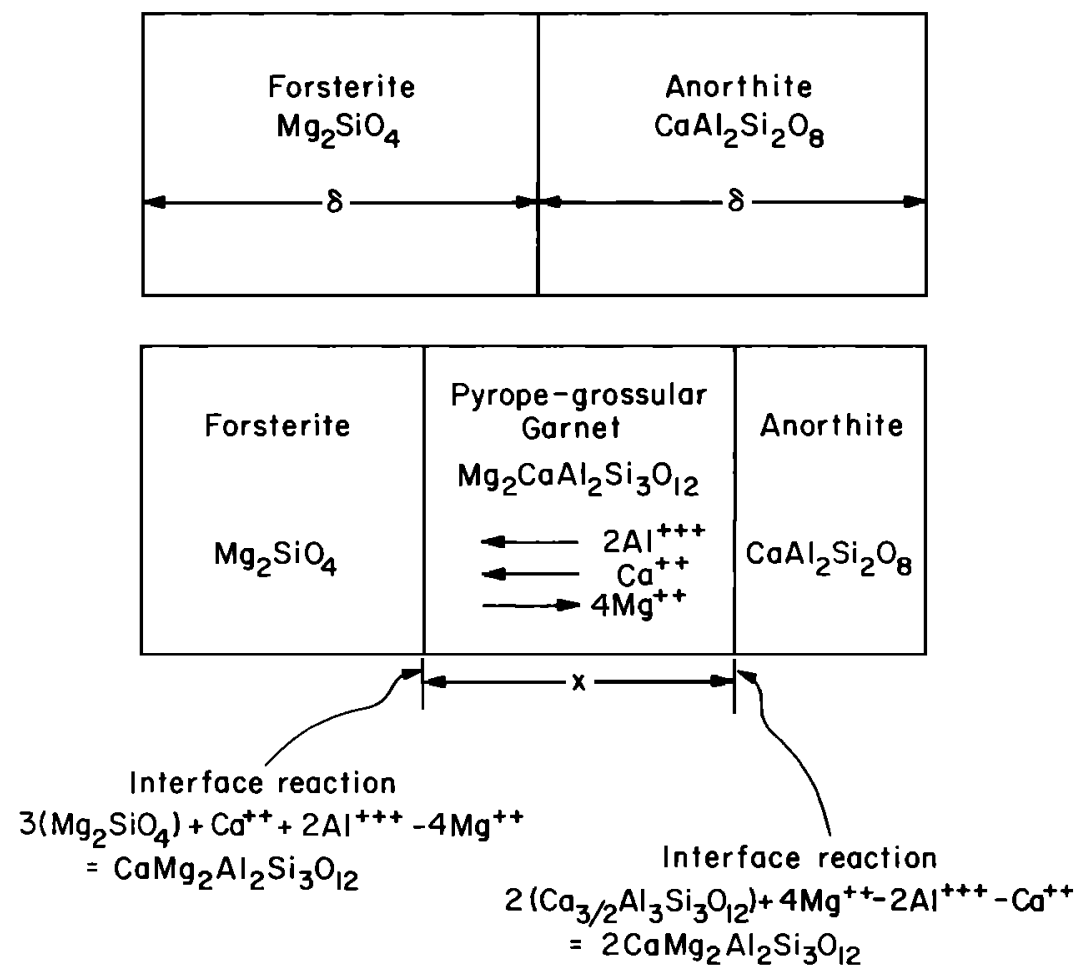

Fig. 4. Solid state diffusion model for the formation of garnet in the reaction $\mathrm{Mg}_{2} \mathrm{SiO}_{4}$ (forsterite) $+\mathrm{CaAl}_{2} \mathrm{Si}_{3} \mathrm{O}_{8}$ (anorthite) $\rightarrow \mathrm{Mg}_{2} \mathrm{CaAl}_{2} \mathrm{Si}_{4} \mathrm{O}_{12}$ (garnet). The thickness of initıal forsterite and anorthite grains is $\delta$, and the thickness of the growing garnet region is $x$. The diffusion of the cations $\mathrm{Al}^{+++}, \mathrm{Ca}^{++}$, and $\mathrm{Mg}^{++}$across the garnet region limits the rate of reaction.

we are also assuming that the reaction is taking place at close to but not precisely at conditions of thermodynamic equilibrium and hence that the free energy of the ions in the garnet is not quite equal to that in the other two species. The cation flux $F$ is also related to the increase in thickness of the garnet region by

$$
F \propto C_{g a} \dot{x}
$$

where $C_{g a}$ is the concentration of the reaction-limiting ion in garnet and $\dot{x}$ is the time rate of change of the garnet crystal thickness. Equations (2) and (3) yield

$$
x \dot{x} \propto D \frac{C}{C_{0 a}}
$$

If $\delta$ is the grain size characteristic of the plagioclase and olivine, the volume fraction of garnet formed, $\Psi$, is

$$
\Psi=x / 2 \delta
$$

Thus using (4) and (5), we find the transformation rate law

$$
\Psi \dot{\Psi} \propto \frac{D}{4 \delta^{2}} \frac{C}{C_{o a}} \quad \Psi \dot{\Psi}=K_{0} \frac{D}{\delta^{2}}
$$

where $K_{0}$ is a constant taken as 1 . If $D$ were constant, integration of (6) would yield a reaction or growth law of the form

$$
\Psi^{2} \propto t
$$

where $t$ is time. As pointed out by Jost [1960], this parabolic growth law is often experimentally observed in tarnishing and other interface reactions involving solids. This type of time dependence was explicitly observed by Augers et al. [1972] and Davis and Park [1972] upon growth of $\mathrm{CaZrO}_{3}$ and $\mathrm{Al}_{2} \mathrm{SiO}_{5}$ at interfaces. The characteristic reaction time for the formation of garnet $\tau$ is

$$
\tau \equiv \frac{\delta^{2}}{K_{0} D}=\frac{\delta^{2}}{K_{0} D_{0} e^{-\Delta G / R T}} \equiv \tau_{0} e^{A / T}
$$

where $T$ is the temperature in degrees Kelvin, $\Delta G$ is the diffusion activation energy, $R$ is the gas constant, $A$ is $\Delta G / R, D_{0}$ is the diffusion frequency term, and $\tau_{0}$ is $\delta^{2} / K_{0} D_{0}$.

We now examine the values of $\tau_{0}$ and $A$ which are required to form garnet (eclogite) in lower crustal and upper mantle environments on time scales of $10^{5}-10^{6} \mathrm{yr}$ and $10^{7}-10^{8} \mathrm{yr}$. These are of interest as they represent times required to transform gabbro to eclogite on tectonically significant distance scales of $\sim 10-100 \mathrm{~km}$ and $\sim 10^{3}-10^{4} \mathrm{~km}$, respectively, in the subducting oceanic crust [Ringwood and Green, 1966; Schubert and Turcotte, 1972] and in the suboceanic lithosphere as the latter moves away from an ocean ridge [Press, 1969; Forsyth and Press, 1971]. Equation (8) determines values of $A$ as a function of $\tau_{0}$ for which a reaction time $\tau$ would be achieved at a temperature $T$. Figure 5 shows $A$ versus $\tau_{0}$ for reaction times of $10^{5} \mathrm{yr}$ (solid lines) and $10^{6} \mathrm{yr}$ (dashed lines) at temperatures between $700^{\circ}$ and $1200^{\circ} \mathrm{K}$. For example, with $A=3 \times 10^{4}{ }^{\circ} \mathrm{K}$ and $\tau_{0}=10^{-2} \mathrm{~s}$, the reaction time would be $10^{5} \mathrm{yr}$ at $900^{\circ} \mathrm{K}$. The distance interval listed with each temperature is an approximate measure of the distance along the slip zone of a subducting slab at which that temperature is reached as a result of frictional heating [Turcotte and Schubert, 1973]. In addition, Figure 5 shows $A$ versus $\tau_{0}$ for a reaction time of $10^{8}$ $\mathrm{yr}$ and temperatures of $700^{\circ}$ and $800^{\circ} \mathrm{K}$, appropriate to the movement of suboceanic lithosphere laterally away from a rise.

By comparing the plots of $A$ versus $\tau_{0}$ with values of these parameters inferred from the limited self-diffusion and binary diffusion data available for related materials and summarized in Table 1 (no explicit diffusion data exist for garnet), we can assess whether solid state diffusion is a mechanism capable of 
TABLE 1. Solid State Diffusion Data

\begin{tabular}{|c|c|c|c|c|c|}
\hline $\begin{array}{l}\text { Diffusing } \\
\text { Species }\end{array}$ & Host & $\begin{array}{c}\text { Temperature Range } \\
\text { of Data, }{ }^{\circ} \mathrm{C}\end{array}$ & $\begin{array}{c}D_{0} \\
\mathrm{~cm}^{2} / \mathrm{s}\end{array}$ & $\begin{array}{c}\Delta G, \\
\mathrm{kCal} / \mathrm{mol}\end{array}$ & Source \\
\hline \multirow[t]{7}{*}{$\mathrm{Ca}^{++}$} & $\alpha^{\prime}-\mathrm{Ca}_{2} \mathrm{SiO}_{4}$ & $1165-1514$ & 0.036 & $\begin{array}{l}65 \\
55\end{array}$ & Fyfe and Verhoogen [1958] \\
\hline & $\begin{array}{l}\alpha-\mathrm{Ca}_{2} \mathrm{SiO}_{4} \\
\alpha-\mathrm{CaSiO}_{2}\end{array}$ & $\begin{array}{c}1165-1514 \\
\ldots\end{array}$ & $\begin{array}{r}0.02 \\
70.000\end{array}$ & $\begin{array}{r}55 \\
112\end{array}$ & Fyfe and Verhoogen [1958] \\
\hline & $\beta-\mathrm{CaSiO}_{3}$ & $\cdots$ & 0.2 & 78 & Lindner [1955] \\
\hline & $\mathrm{CaSi}_{2} \mathrm{O}_{7}$ & $\cdots$ & 0.01 & 73 & Lindner [1955] \\
\hline & $\mathrm{CaFe}_{2} \mathrm{O}_{4}$ & & 30. & 86 & Fyfe and Verhoogen [1958] \\
\hline & $\mathrm{CaO}$ & & 0.4 & 81 & Lindner [1955] \\
\hline & $\mathrm{CaO}$ & $1465-1760$ & $11.75 \times 10^{-5}$ & 64.3 & Kumer and Gupta [1969] \\
\hline \multirow{2}{*}{$\mathrm{Mg}^{++}-\mathrm{Fe}^{++*}$} & $(\mathrm{Mg}, \mathrm{Fe})_{2} \mathrm{SiO}_{4}$ & $1000-1100$ & $3.7 \times 10^{-7}$ & 28.8 & Buening and Buseck [1973]† \\
\hline & $(\mathrm{Mg}, \mathrm{Fe})_{2} \mathrm{SiO}_{4}$ & $900-1100$ & $3.4 \times 10^{-3}$ & 47 & Meisner $[1972] \ddagger$ \\
\hline \multirow{3}{*}{$\begin{array}{l}\mathrm{Ca}^{++} \\
\mathrm{Mg}^{++}\end{array}$} & $\mathrm{MgO}$ & $790-1850$ & $8.9 \times 10^{-4}$ & 63.67 & Wuensch and Vasilos [1968] \\
\hline & $\mathrm{MgO}$ & $1400-1600$ & 0.249 & 79.13 & Wuensch and Vasilos [1968] \\
\hline & $\mathrm{MgAl}_{2} \mathrm{O}_{4}$ & - & 200. & 86.0 & Lindner and Akerström [1958] \\
\hline \multirow[t]{2}{*}{$\mathrm{Fe}^{++}$} & $\mathrm{MgO}$ & $\ldots$ & $8.83 \times 10^{-3}$ & 41.75 & Wuensch and Vasilos [1968] \\
\hline & $\mathrm{MgO}$ & ‥ & $3.2 \times 10^{-4}$ & 41.99 & Wuensch and Vasilos [1968] \\
\hline $\mathrm{Al}^{+++}$ & $\mathrm{Al}_{2} \mathrm{O}_{3}$ & & 27.54 & 114 & Birchenall [1968] \\
\hline $\mathrm{Na}^{++}$ & perthite & 550 & $10^{-11}-10^{-12} \S$ & & Fyfe and Verhoogen [1958] \\
\hline $\mathrm{Na}-\mathrm{K}$ & $\mathrm{KAl}_{2} \mathrm{Si}_{8} \mathrm{O}_{8}-\mathrm{NaAl}_{2} \mathrm{Si}_{3} \mathrm{O}_{8}$ & 1020-1088 & $1.5 \times 10^{19}$ & 167 & Fyfe and Verhoogen [1958] \\
\hline
\end{tabular}

* Interdiffusion of $\mathrm{Fe}^{++}-\mathrm{Mg}^{++}$in olivine.

t Along $C$ axis, $p\left(\mathrm{O}_{2}\right)=10^{-12} \mathrm{~atm}, 10 \mathrm{wt} \% \mathrm{Fe}$.

¥ Along $C$ axis, 5 wt $\% \mathrm{Mg}^{++}$.

$\S$ Values given are the range of diffusion constants.

yielding the gabbro-eclogite transformation at temperatures and on time scales of interest. The values of $\tau_{0}$ and $A$ shown in Figure $\mathbf{5}$ for various pertinent minerals are calculated for the grain size range which we believe describes oceanic gabbros and accompanying basalts, $0.1-1 \mathrm{~cm}$. We think that the recent binary diffusion data for olivine [Meisner, 1973; Buening and Buseck, 1973] and the previous data for $\mathrm{Al}^{+++}$diffusion in $\mathrm{Al}_{2} \mathrm{O}_{3}$ [Paladino and Kingery, 1962] delineate the range of possibilities for garnet. (For the present purposes, we are neglecting the small decrease of diffusivity with compression.) Although activation energies for multicomponent diffusion in garnet could conceivably be as low as the $29 \mathrm{kcal} / \mathrm{mol}$ reported by Buening and Buseck [1973] below $1125^{\circ} \mathrm{C}$ in olivine, we infer from previous examination of complex diffusion systems [Cooper, 1965; Schmalzreid, 1969; Buckley, 1973] that the effective ternary diffusion constant for reaction (1) is more likely within one order of magnitude of the value of the diffusivities of the slowest moving species, in our case, $\mathrm{Al}^{+++}$. The examples given by Buckley [1973] further suggest that the activation energy in the case of a binary system is also close to that of the slowest diffusing end member. (Since in ideal solutions the binary diffusion fluxes are, at thermodynamic equilibrium, linear combinations of end member self-diffusion fluxes, for the present purpose we have not differentiated between binary and self-diffusion data.)

The question of whether cation diffusion in a polycrystalline aggregate can be controlled (and presumably occur more rapidly) by surface diffusion processes has been examined by Paladino and Coble [1963] and Mistler and Coble [1971]. They conclude that cation-diffusion is usually independent of grain boundaries in ionic compounds although they point out that some exceptions do occur. In the case of $\mathrm{Al}_{2} \mathrm{O}_{3}$ they find that apparent self-diffusion coefficients (surface diffusion) for oxygen are greater than those for $\mathrm{Al}^{+++}$only in aggregates having crystallites smaller than $20 \mu$. We conclude that there are insufficient experimental data at present to assess the possible importance of solid state surface diffusion processes as they pertain to the basalt- or gabbro-eclogite reaction rate.

From Figure 5 we infer that if the effective bulk diffusion constant for the gabbro-eclogite transition is similar to that of
$\mathrm{Al}^{+++}$in $\mathrm{Al}_{2} \mathrm{O}_{3}$, solid state diffusion cannot produce the gabbro-eclogite transformation on the required time scale below $\sim 900^{\circ} \mathrm{C}$ within the oceanic crust during subduction and within the suboceanic lithosphere as spreading from a ridge takes place. However, if diffusion activation energies of $\sim 30 \mathrm{kcal} /$ mol, such as those found for $\mathrm{Mg}^{++}-\mathrm{Fe}^{++}$diffusion in olivines, are more typical of the diffusion constant associated with solid state growth of garnet (a possibility we believe to be less likely), then minimum gabbro-eclogite transformation temperatures of $\sim 600^{\circ} \mathrm{C}$ are a possibility. However, the usual occurrence of strongly zoned metamorphic garnets in nature [e.g., Graham and Ahrens, 1973] strongly suggests that diffusion in garnet occurs very slowly at crustal temperatures.

Recent studies of the reactivity and sintering of silicates [Burte and Nicholson, 1972; Cutler, 1969] have demonstrated that recrystallization rates in a parabolic growth (7) can be enhanced by the presence of water vapor at low partial pressures $(<1 \mathrm{~atm})$. Although the rates seem to be controlled by bulk diffusion through silicate lattices, it appears that water vapor tends to react with the $\mathrm{SiO}_{4}{ }^{-}$bonds in the manner

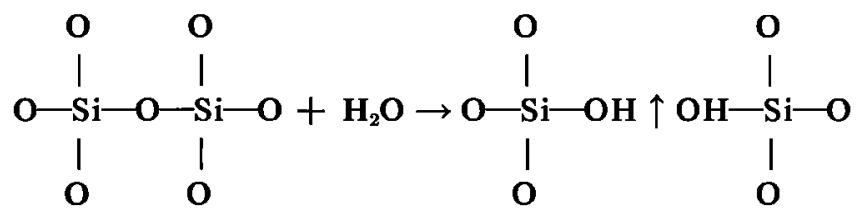

and effectively provide a broken bridge $(\uparrow)$ in the lattice. According to Burte and Nicholson [1972], this type of reaction results in an effective $\mathrm{O}^{-}$vacancy production, which in turn will enhance cation bulk diffusion via interstitial sites in the silicate lattice. A detailed model for this effect has not yet been proposed, although a similar mechanism has been discussed by Greenwood [1963] in his study of the synthesis of anthophyllite.

\section{Grain InTERstitial Diffusion}

In the preceding section we have demonstrated that under totally dry conditions in the relatively cool down-going slab or in the spreading suboceanic lithosphere, solid state diffusion processes appear to be too slow to bring about the gabbro-eclogite transformation on the necessary time scale. If 


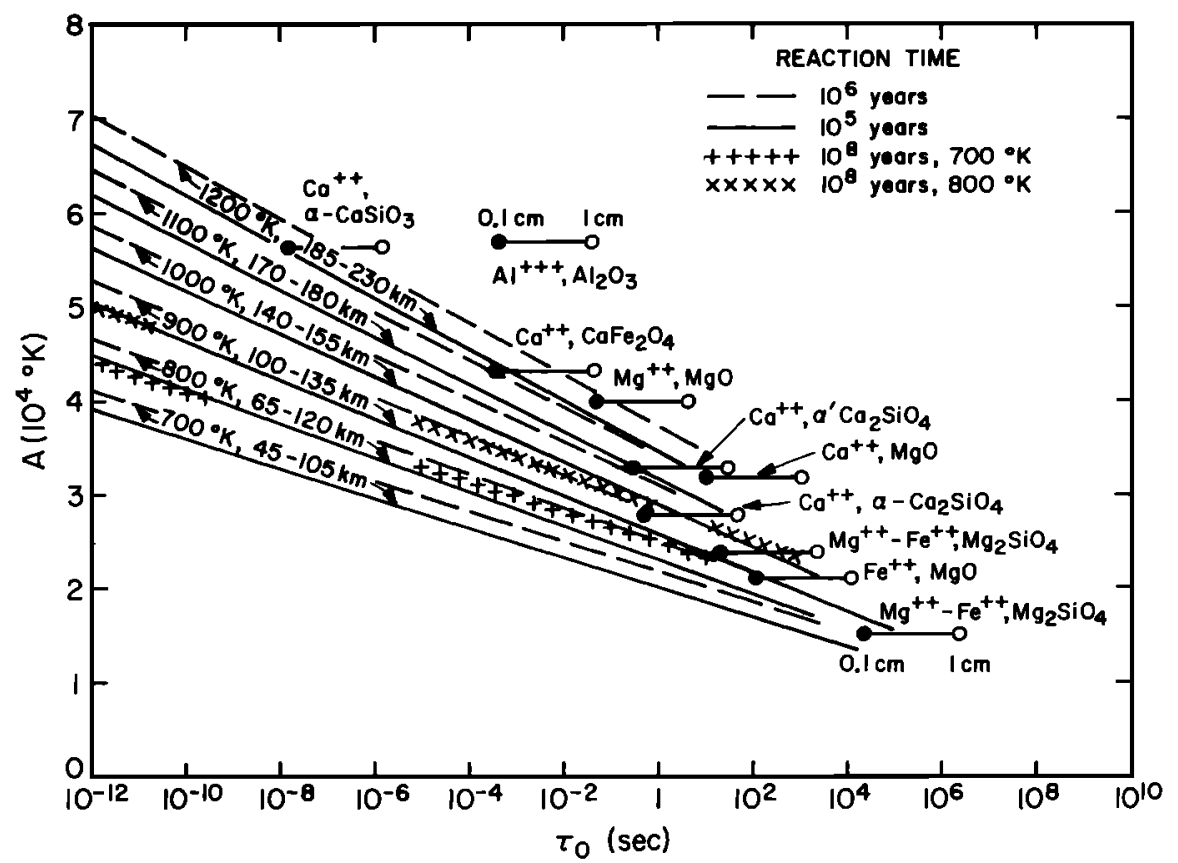

Fig. 5. Solid state diffusion activation energy $A=\Delta G / R$ versus diffusion frequency parameter $\tau_{0}=\delta^{2} / K_{0} D_{0}$ for gabbro-eclogite reaction times of $10^{5}, 10^{\circ}$, and $10^{\mathrm{A}} \mathrm{yr}$ at various temperatures. Distance intervals corresponding to a given temperature indicate the approximate distance along the slip zone of a subducting slab at which that temperature is reached via frictional heating. Also shown are values of $A$ and $\tau_{0}$ for 0.1 - and $1.0-\mathrm{cm}$ grain sizes inferred from measurements of selldiffusion in various minerals (Table 1).

minute amounts of water are present, the rate of reaction may be speeded up via the formation of vacancies as a result of broken $\mathrm{Si}-\mathrm{O}^{-}$structural bridges or through a transport mechanism that we refer to as grain interstitial diflusion. In this latter process, ions involved in the gabbro-eclogite transformation migrate through a thin film of interstitial water vapor to sites of garnet formation, as depicted in Figure 6.

It seems generally accepted that water is a minor constituent of the earth's crust [Ronov and Yaroshevsky, 1969; Vinogradov, 1967; Poldervaart, 1955], while studies of mantle-derived ultramafic nodules and rocks show that small amounts of phlogopite and amphibole are to be found in the upper mantle [Wyllie, 1971] and recently, still another water-bearing mineral, titanoclinohumite, has been identified as probably being derived from the mantle [McGetchin et al., 1970]. Very recently, Giardini et al. [1974] have found biotite as a primary inclusion in diamond. The thermal regime calculations by $T u r-$ cotte and Schubert [1973] demonstrate that the portion of island arc andesitic volcanism over a subduction zone correlates well with the achievement of the solidus temperature $\sim 1100^{\circ} \mathrm{C}$ in basaltic rocks containing small quantities of water. The work of Essene et al. [1970] on amphibolecontaining basalts shows that if the water content is small, the eclogite stability remains similar to that of dry basalts over the range of pressures and temperatures studied in the dry systems. Wyllie [1970] has also noted that the presence of a small amount of water would probably not affect the phase relationships below the solidus. The effect of water vapor, possibly with some dissolved $\mathrm{CO}_{2}$ or $\mathrm{N}_{2}$, either in excess or in the undersaturated situation in vapor pressure equilibrium with the minerals serpentine [Kitahara et al., 1966], anthophyllite [Evans and Trommsdorf. 1970], amphiboles [Essene et al., 1970; Oxburgh, 1964; Kushiro et al., 1967], or micas [Allen et al., 1972; Modreski and Boettcher, 1973], which can exist to successively greater depths down to at least $100 \mathrm{~km}$, is explored in the following section.
It is assumed that small quantities of water exist as part of an interstitial fluid, the other components of which may be $\mathrm{CO}_{2}$ or $\mathrm{N}_{2}$, and thus the $\mathrm{H}_{2} \mathrm{O}$ vapor pressure $\left(P_{\mathrm{H}_{2} \mathrm{O}}\right)$ may be less than the total pressure $\boldsymbol{P}_{\boldsymbol{T}}$. In general, the water will be above the $374^{\circ} \mathrm{C}$ and 221 bar critical point, at a pressure greater than (if it is in excess) or equal to the pressure of water in equilibrium with the existing minerals. The interstitial water is thus capable of transporting ions in solution. The effect of excess water on the equilibrium for the greenschist-amphiboliteeclogite transformation has been investigated by Essene et al. [1970] and Allen et al. [1972]. If the rocks of the lithosphere are water-saturated (an assumption which the laboratory data from the extreme lowering of melting intervals argue against [Hill and Boettcher, 1970]), the equilibrium transformation of amphibolite to eclogite will occur at considerably higher pressure than in the undersaturated basalt- or gabbro-eclogite system (Figure 7). In the water-saturated situation, transformation rates (schist, amphibolite-eclogite) are quite rapid, as is shown below.

According to the grain interstitial diffusion model, the gabbro-eclogite (or, if saturated, the greenschist, amphibolite-eclogite) transformation rate could be limited either by the ease with which ions can dissolve in the inter-

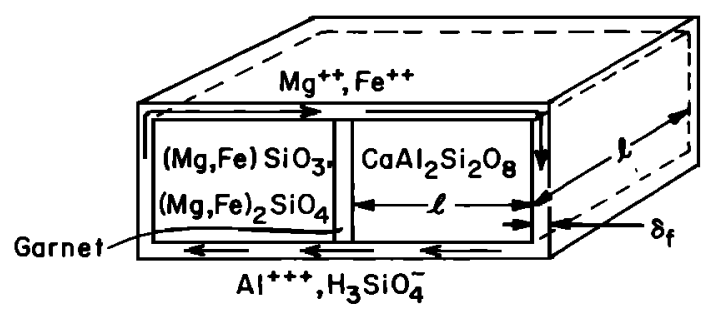

Fig. 6. Schematic of grain interstitial diffusion model for basalteclogite reaction. Cations dissolve in water of film thickness $\delta_{r}$ surrounding forsterite and anorthite grains of size $l$ and diffuse to sites of garnet formation. 


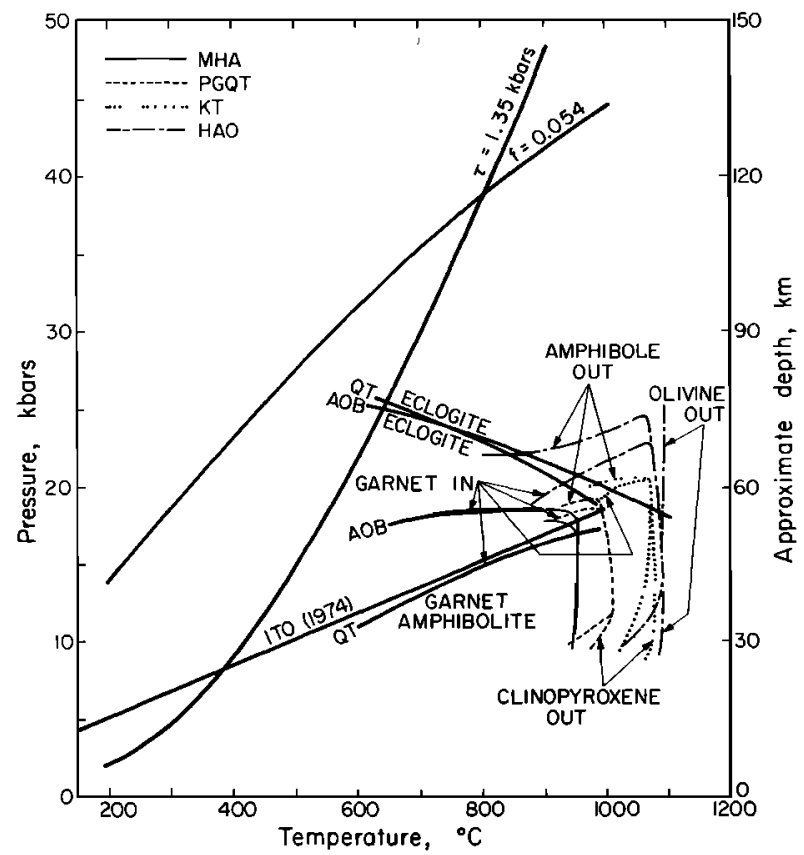

Fig. 7. Stability field of basic rocks containing amphibole, $\boldsymbol{P}_{\mathrm{H}_{2} \mathrm{O}}$ $=P_{T}$. At high pressures (18 to $25 \mathrm{kbar}$ ) various low-temperature (below $950^{\circ}-1075^{\circ} \mathrm{C}$ ) eclogites are formed. At higher temperatures partial melting occurs. MHA, PGQT, KT, and HAO indicate Mount Hood andesite, Picture Gorge quartz tholeiite, 1921 Kilauea tholeiite, and Hualalai alkali olivine basalt [Allen et al., 1972], and QT and AOB approximate stability fields for quartz tholeiite and alkali olivine basalt [from Essene et al., 1970].

stitial water film or by their mobility in diffusion through the water. We consider each effect separately, first examining the effective diffusion constants if the pertinent ions needed to crystallize garnets were available in the interstitial fluid solution. Diffusion constants at ambient pressures and temperatures up to $\sim 100^{\circ} \mathrm{C}$ for cations such as $\mathrm{Na}^{+}, \mathrm{K}^{+}$, and $\mathrm{Ca}^{++}$are all of rather similar magnitude, varying from $\sim 10^{-5}$ to $10^{-4} \mathrm{~cm}^{2} / \mathrm{s}$ [Longworth, 1972]. Walton [1960] has in fact shown that in the crust the molecular components of rocks, including silica, have, in aqueous solution, diffusivities of the order of $10^{-3}-10^{-4} \mathrm{~cm}^{2} / \mathrm{s}$ under a wide range of temperature and pressure. Were the ions required for the transformation of basalt to eclogite, from a simple picture such as that shown in Figure 6, present in sufficient concentration in a film of fluid surrounding each grain, then straightforward application of (8), with $D$ (conservatively) varying from $10^{-4}$ to $10^{-5} \mathrm{~cm}^{2} / \mathrm{s}$, would yield time constants of only $\sim 3-30$ days for $1-\mathrm{cm}$ grains.

Under ordinary near-surface conditions, even when water participates in other silicate equilibrium reactions, the transformation rates are slow because the normal concentration of the necessary ions in the interstitial solution is far too low. An estimate of the concentration of ions participating in typical silicate reactions in a predominantly water interstitial fluid at standard conditions can be obtained by using the Garrels and Christ [1965] estimate of the standard free energy of the ion $\mathrm{H}_{3} \mathrm{SiO}_{4}{ }^{-}$, in aqueous solution, of $-286.8 \mathrm{kcal} / \mathrm{mol}$. Straightforward application of the directly determined thermochemical data [Robie and Waldbaum, 1968] for solution and ionization of $\mathrm{MgSiO}_{3}, \mathrm{CaAl}_{2} \mathrm{Si}_{2} \mathrm{O}_{8}$, and $\mathrm{Mg}_{2} \mathrm{SiO}_{4}$ yields values of the $\mathrm{Mg}^{++}$and $\mathrm{Al}^{+++}$concentrations of $\sim 1 \times 10^{-5} \mathrm{~mol} / \mathrm{l}$ and $2 \times 10^{-13} \mathrm{~mol} / 1$, respectively. These values were calculated assuming the $p \mathrm{H}$ of seawater. For neutral water the above estimates must be increased by factors of $\sim 4$ and $\sim 25$, respectively. The above concentration values imply unacceptably long reaction times.

In contrast to near-surface conditions, in a water-saturated system at depth, eclogite forms above $19 \pm 7 \mathrm{kbar}$ (Figure 7). At this pressure, Figure 13 demonstrates that ion solubility is sufficiently great that the amphibolite-eclogite transition will occur rapidly.

Since ample evidence exists that some water-bearing minerals are present in virtually all mantle-derived rocks and since melting data for water-saturated basaltic compositions indicate that it is unlikely that the lithospheric rocks are fully water-saturated, it is important to consider the conditions in unsaturated rocks which are required to enhance the reaction rates associated with the gabbro-eclogite transformation. For water vapor to exist inside voids within minerals or along grain boundaries and yet not be in excess requires either that another fluid phase(s) be present, such that the partial pressure of the other phase(s) plus $P_{\mathrm{H}_{2} \mathrm{O}}$ is equal to $P_{T}$, or that $P_{\mathrm{H}_{2} \mathrm{O}}<P_{T}$ and that the rock be able to support kilobar-level stress differences over a grain size distance scale. Although it has long been believed that the small openings in samples of crustal and mantle rocks are a superficial effect, recent observations of equant pores in crustal rocks [e.g., Brace et al., 1972], in crustal pyroxene in eclogite [Champness et al., 1974], and olivine from diamond pipes [Green, 1972] demonstrate that small openings can in fact exist within deeply buried rocks. From the observations of openings within pyroxenes, Champness et al. [1974] suggest that in the crust, eclogites might crystallize at low temperature as a result of ion transport in a fluid phase. These authors carried out microprobe analyses for a trace of chlorine in these holes (possibly from connate seawater) but found none. They suggested instead that where a melange of ocean floor material, including sediment, is subducted, sufficient quantities of $\mathrm{N}_{2}$ may be trapped, such that

$$
P_{\text {fluld }}=P_{\mathrm{N}_{2}}+P_{\mathrm{H}_{2} \mathrm{O}}+P_{\mathrm{CO}_{2}} \cdot . \simeq P_{\mathrm{T}}
$$

In this case even though the partial pressure of water is low, it may be sufficient to provide the high-diffusivity medium needed to produce the gabbro-eclogite transformation at low temperatures within geologically significant time scales.

\section{Vapor Pressure of Hydrous Minerals}

Of major concern in recent studies of the stability of hydrous minerals such as serpentine, chlorite, tremolite, talc, and phlogopite at high temperatures and pressures has been their dehydration, which can then give rise to partial melting in the upper mantle. Our concern in the present paper is the vapor pressure associated with the suboceanic basaltic lithosphere both below the ocean. floor and upon subduction into the mantle. Although it is likely that only a small percentage of hydrous phases are present in most of an undersaturated lithosphere, the presence of these hydrous phases, even if only in trace quantities, will give rise to a nonzero $\mathrm{H}_{2} \mathrm{O}$ vapor pressure if either another gaseous phase (e.g., $\mathrm{CO}_{2}, \mathrm{~N}_{2}$ ) is present or the grains within the rock can support kilobar stress differences over distances comparable to the grain size. Thus within each grain of a hydrous mineral, a low but nonnegligible $P_{\mathrm{H}_{2} \mathrm{O}}$ will be present at temperatures below the dehydration temperature by the very existence of the hydrous mineral. (The value of $P_{\mathrm{H}_{2} \mathrm{O}}$ will only equal the $P_{T}$ at the temperature and pressure associated with dehydration, if no other gases are present.) The water vapor pressures associated 
TABLE 2. Vapor Pressure in Kilobars for Serpentine, $\mathrm{Mg}_{3} \mathrm{Si}_{2} \mathrm{O}_{5}(\mathrm{OH})_{4}$

\begin{tabular}{|c|c|c|c|c|c|c|c|c|c|c|c|}
\hline \multirow{2}{*}{$\begin{array}{c}\text { Temper- } \\
\text { ature, } \\
{ }^{\circ} \mathrm{K}\end{array}$} & \multicolumn{11}{|c|}{ Total Pressure, kbar } \\
\hline & 1 & 2.5 & 5 & 10 & 15 & 20 & 25 & 30 & 35 & 40 & 50 \\
\hline 400 & & & & 0.41 & 4.86 & 10.11 & 15.75 & 21.68 & & & \\
\hline 500 & 0.14 & 0.22 & 0.37 & 2.89 & 7.68 & 12.74 & 18.54 & 24.43 & 30.60 & 37.01 & $50.24^{*}$ \\
\hline 600 & 0.42 & 0.48 & 1.82 & 6.14 & 11.05 & 16.34 & 21.97 & 27.87 & 34.04 & $40.31^{*}$ & \\
\hline 700 & $1.11^{*}$ & 2.11 & 4.02 & 8.39 & 13.32 & 18.59 & 24.18 & $30.01 *$ & $36.12^{*}$ & & \\
\hline 800 & & & & $11.18^{*}$ & & & & & & & \\
\hline
\end{tabular}

* Calculated vapor pressure exceeds total pressure, indicating $\mathrm{H}_{2} \mathrm{O}$ is stable.

with the presence of serpentine, tremolite, and talc were calculated using the following reactions, which are taken to be typical for the spontaneous breakdown of each mineral below its dehydration temperature:

$$
\begin{gathered}
\underset{\text { serpentine }}{1 / 2 \mathrm{Mg}_{9} \mathrm{Si}_{2} \mathrm{O}_{5}(\mathrm{OH})_{4}} \rightarrow \underset{\text { enstatite }}{1 / 2 \mathrm{MgSiO}_{3}}+\underset{\text { forsterite }}{1 / 2 \mathrm{Mg}_{2} \mathrm{SiO}_{4}}+\mathrm{H}_{2} \mathrm{O}(v) \\
\underset{\text { tremolite }}{\mathrm{Ca}_{2} \mathrm{Mg}_{5}\left(\mathrm{Si}_{8} \mathrm{O}_{22}\right)(\mathrm{OH})_{2}} \rightarrow \\
\underset{\text { diopside }}{2 \mathrm{CaMgSi}_{2} \mathrm{O}_{6}}+\underset{\text { enstatite }}{3 \mathrm{MgSiO}_{3}}+\underset{\text { quartz }}{\mathrm{SiO}_{2}}+\mathrm{H}_{2} \mathrm{O}(v) \\
\underset{\text { talc }}{\mathrm{Mg}_{3} \mathrm{Si}_{4} \mathrm{O}_{10}(\mathrm{OH})_{2}} \rightarrow \underset{\text { enstatite }}{3 \mathrm{MgSiO}_{3}}+\underset{\text { quartz }}{\mathrm{SiO}_{2}}+\mathrm{H}_{2} \mathrm{O}(v)
\end{gathered}
$$

These water vapor pressures are the osmotic equilibrium pressures of water associated with each of these minerals [Greenwood, 1961]. In the actual assemblages involved in the gabbro-eclogite transition, higher values of $\boldsymbol{P}_{\mathrm{H}_{2} \mathrm{O}}$ may occur. The vapor pressure $P_{\mathrm{H}_{2} \mathrm{O}}$, which we take to be the minimum value which can be associated with each of the above minerals, was numerically calculated using [Kern and Weisbrod, 1967]

$$
\Delta G_{T}{ }^{0}=\int_{1 \text { bar }}^{P T} \Delta V_{T}^{*} d P+\int_{1 \text { bar }}^{P_{\mathrm{H}_{2} \mathrm{O}}} V_{\mathrm{H}_{2} \mathrm{O}} d P
$$

Here $\Delta G_{T}{ }^{0}$ is the difference in molar free energy of the mineral between the pressures $P_{T}$ and 1 bar at temperature $T, \Delta V_{T}{ }^{8}$ is the molar volume change of the solid phases between the pressures $P$ and 1 bar at temperature $T$, and $V_{\mathrm{H}_{2} \mathrm{O}}$ is the molar specific volume of water at pressure $P$ and temperature $T$. Although $\Delta V_{T}^{s}$ is also a function of pressure, we have assumed the value at standard conditions [Robie and Waldbaum, 1968], largely because the equations of state of the hydrous minerals are so poorly known.

The results given in Tables 2, 3, and 4 and Figures 8-10 were obtained by using the high-temperature free energy data of Robie and Waldbaum [1968] with the exception of serpentine, for which we used the data of King et al. [1967]. The value of the second integral was obtained from the tabulation of Helgeson and Kirkham [1974] below 10 kbar and by numerical integration using the equation of state tabulation for water given by Kennedy and Holser [1966] above $10 \mathrm{kbar}$.

It should be noted that in Figures 8-10 each line of constant vapor pressure intersects the dehydration reaction boundary at the point where $P_{\mathrm{H}_{2} \mathrm{O}}=\boldsymbol{P}_{T}$. Similar calculations for the reactions forsterite + talc $\rightarrow$ enstatite + water and analcite $\rightarrow$ albite + nepheline + water at low pressures have been carried out by Yoder [1955] and Greenwood [1961]. Greenwood [1961] has derived a series of formulas which give the slope $(\partial P / \partial T)_{P_{\mathrm{H}_{2} \mathrm{O}}}$ and the curvature $\left(\partial^{2} P / \partial T^{2}\right)_{P_{\mathrm{H}_{2} \mathrm{O}}}$ of the lines of constant $P_{\mathrm{H}_{2} \mathrm{O}}$ at the point of intersection with the dehydration curve. The calculated dehydration boundary for reaction (9) (Figure 8) is virtually indistinguishable below $20 \mathrm{kbar}$ from that for the reaction

$$
\underset{\text { serpentine }}{\mathrm{Mg}_{8} \mathrm{Si}_{2} \mathrm{O}_{5}(\mathrm{OH})_{4}}+\underset{\text { brucite }}{\mathrm{Mg}(\mathrm{OH})_{2}} \rightarrow \underset{\text { forsterite }}{2 \mathrm{Mg}_{2} \mathrm{SiO}_{4}}+\mathrm{H}_{2} \mathrm{O}
$$

observed by Kitahara et al. [1966] also shown in the figure. Moreover, Evans and Trommsdorf [1972] have demonstrated that the conditions for the hydration of dunites are relatively insensitive to iron content. In the case of tremolite, the calculated dehydration boundary lies at $\sim 100^{\circ} \mathrm{C}$ higher temperatures but has a shape similar to that computed earlier by Essene et al. [1970] on the basis of estimated thermodynamic properties for tremolite. As can be seen in Figure 10 , the calculated stability field of talc plus diopside relative to tremolite is displaced at 6-7 kbar higher pressure (based on the

\begin{tabular}{|c|c|c|c|c|c|c|c|c|c|c|c|c|}
\hline \multirow{2}{*}{$\begin{array}{c}\text { Temper- } \\
\text { ature, } \\
{ }^{\circ} \mathrm{K}\end{array}$} & \multicolumn{12}{|c|}{ Total Pressure, kbar } \\
\hline & 1 & 2.5 & 5 & 10 & 15 & 20 & 25 & 30 & 35 & 40 & 50 & 60 \\
\hline 400 & & & & & & & & 0.59 & 7.57 & 15.45 & & \\
\hline 500 & & & & & & & 0.31 & 3.85 & 10.98 & 18.87 & 36.40 & 55.76 \\
\hline 600 & & & & & 0.02 & 0.28 & 1.03 & 7.15 & 14.38 & 22.33 & 39.73 & 59.36 \\
\hline 700 & & & & 0.07 & 0.26 & 0.44 & 3.87 & 10.22 & 17.57 & 25.51 & 42.85 & $62.36^{*}$ \\
\hline 800 & & 0.03 & 0.11 & 0.26 & 0.41 & 1.74 & 6.96 & 13.61 & 21.07 & 29.10 & 46.47 & $66.26^{*}$ \\
\hline 900 & 0.16 & 0.20 & 0.27 & 0.40 & 1.69 & 4.54 & 10.28 & 17.44 & 25.13 & 33.40 & $51.50^{*}$ & \\
\hline 1000 & 0.30 & 0.33 & 0.39 & 0.55 & 2.79 & 7.51 & 13.96 & 21.39 & 29.30 & 37.76 & $57.41^{*}$ & \\
\hline 1100 & 0.40 & 0.43 & 0.48 & 1.74 & 5.23 & 10.52 & 17.54 & 25.03 & 33.09 & $41.58^{*}$ & & \\
\hline
\end{tabular}
Robie and Waldbaum [1968] compilation) than that obtained by Essene et al. [1970].

It should be noted that at temperatures below the dehydration temperature of serpentine the vapor pressure associated with serpentine (and probably also, because of its structural similarity, chlorite) is considerably greater than that of tremolite (or talc). Comparison of Figures 9 and 10 or Tables 3

TABLE 3. Vapor Pressure in Kilobars for Tremolite, $\mathrm{Ca}_{2} \mathrm{Mg}_{5}\left[\mathrm{Si}_{8} \mathrm{O}_{12}\right](\mathrm{OH})_{2}$

* Calculated vapor pressure exceeds total pressure, indicating $\mathrm{H}_{2} \mathrm{O}$ is stable. 
TABLE 4. Vapor Pressure in Kilobars for Talc, $\mathrm{Mg}_{3} \mathrm{Si}_{4} \mathrm{O}_{10}(\mathrm{OH})_{2}$

\begin{tabular}{|c|c|c|c|c|c|c|c|c|c|c|c|c|}
\hline \multirow{2}{*}{$\begin{array}{c}\text { Temper- } \\
\text { ature, } \\
{ }^{\circ} \mathrm{K}\end{array}$} & \multicolumn{11}{|c|}{ Total Pressure, kbar } & \multirow[b]{2}{*}{60} \\
\hline & 1.0 & 2.5 & 5 & 10 & 15 & 20 & 25 & 30 & 35 & 40 & 50 & \\
\hline 400 & & & & & & & & 0.49 & 6.01 & 12.24 & & \\
\hline 500 & & & & & & 0.06 & 0.40 & 4.03 & 9.74 & 16.00 & 29.72 & 44.66 \\
\hline 600 & & & & & 0.19 & 0.39 & 2.76 & 7.76 & 13.63 & 19.93 & 33.74 & 48.59 \\
\hline 700 & & 0.02 & 0.10 & 0.25 & 0.40 & 1.60 & 6.14 & 11.57 & 17.55 & 23.95 & 37.73 & 52.68 \\
\hline 800 & & 0,23 & 0.29 & 0.41 & 1.07 & 4.84 & 9.75 & 15.42 & 21.57 & 28.07 & 41.90 & 57.30 \\
\hline 900 & 0.34 & 0.38 & 0.43 & 0.92 & 3.84 & 8.22 & 13.63 & 19.59 & 22.93 & 32.62 & 46.94 & $63.57^{*}$ \\
\hline 1000 & 0.46 & 0.49 & 0.87 & 3.03 & 6.84 & 11.76 & 17.59 & 23.76 & 30.24 & 37.13 & $52.40^{*}$ & \\
\hline 1100 & $1.78^{*}$ & 2.41 & 3.81 & 7.55 & 12.49 & 18.24 & 24.31 & $30.72^{*}$ & & & & \\
\hline
\end{tabular}

* Calculated vapor pressure exceeds total pressure, indicating $\mathrm{H}_{2} \mathrm{O}$ is stable.

and 4 demonstrates that the vapor pressures associated with talc and tremolite are similar. The considerably higher vapor pressure associated with serpentine or chlorite implies, as Fry and Fyfe [1969] have pointed out, that if eclogite forms in communication with other minerals, serpentine or chlorite generally would be expected to dehydrate in favor of forming amphibole (tremolite or talc if sufficient $\mathrm{Ca}$ exists in the system) at high pressures. Although some tremolite is formed associated with serpentine in the metamorphosed ultramafic rocks of the Alps, studies of the mineral assemblages present [Evans and Trommsdorf. 1970] demonstrate that talc and serpentine are not found in the same rocks. Although we are only considering three minerals, we would generally expect that if both olivine and pyroxene are present, a water-deficient system will tend to form amphibole at the expense of serpentine. Upon subduction at relatively low temperature, talc will form at pressures above $\sim 25-30$ kbar at the expense of serpen-

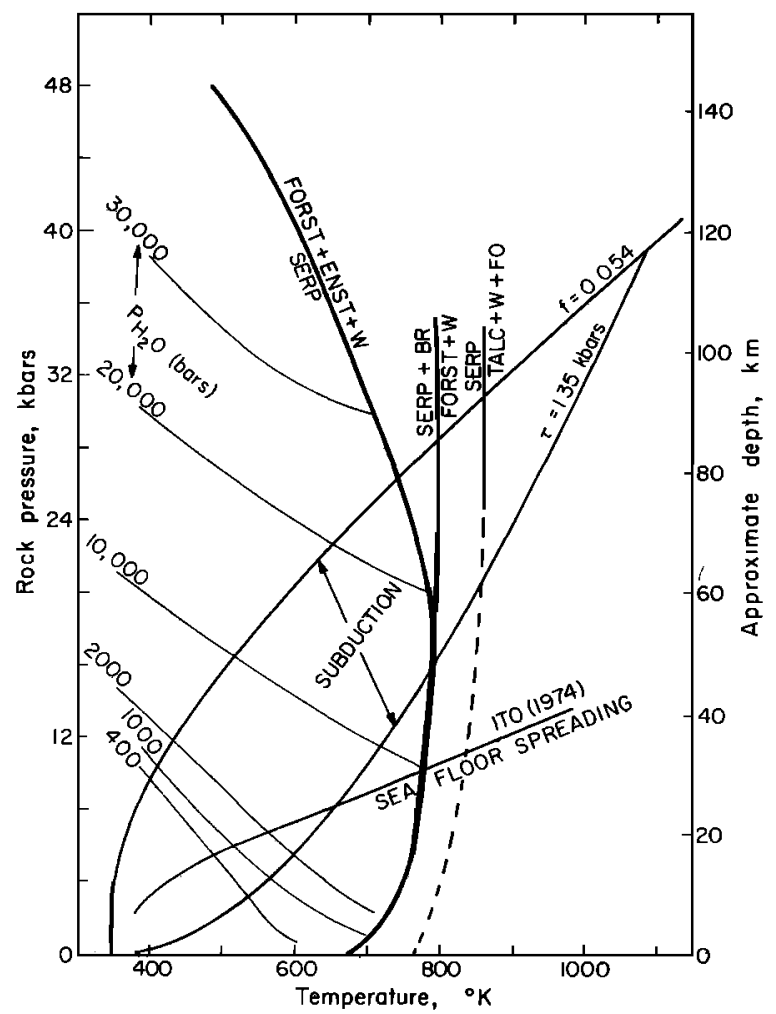

Fig. 8. Vapor pressure of $\mathrm{H}_{2} \mathrm{O}$ associated with pure serpentine for spontaneous dehydration, according to reaction (9), as a function of temperature and total pressure. Possible thermodynamic paths for the top of the subducting lithosphere are shown as lines of constant $\tau$ and $f$ [Turcotte and Schubert, 1973]. tine and probably chlorite. Thus we expect chlorite or serpentine to control the minimum $\boldsymbol{P}_{\mathrm{H}_{2} \mathrm{O}}$ only in the case of silicapoor rocks containing little pyroxene.

We conclude this section by estimating the reaction time for the interstitial diffusion mechanism, given the concentration of ionic species in the water containing fluid film. In our model, ionic transport takes place within a thin film of fluid (thickness $\delta_{f}$ ) within and around each crystal grain along a length $l$, as shown in Figure 6. If pore fluid occupies a very small fraction of the rock volume, as is assumed here, the mass fraction of fluid $m_{f}$ is given by

$$
m_{f}=G \frac{\delta_{f}}{l} \frac{\rho_{f}}{\rho_{r}}
$$

where $G$ is a geometrical factor, equal to 3 in the case of cubeshaped crystals, and $\rho_{f}$ and $\rho_{r}$ are the mass densities of the fluid and rock, respectively. Assuming that $G=3, \delta_{r}=10^{-5}-10^{-6}$ $\mathrm{cm}, l=1 \mathrm{~cm}, \rho_{r} \sim 1 \mathrm{~g} / \mathrm{cm}^{3}$, and $\rho_{r} \sim 3 \mathrm{~g} / \mathrm{cm}^{3}$, we find $m_{f}=$ $10^{-5}-10^{-6}$. This value of $m_{f}$ is certainly an overestimate, as it is unlikely that continuous fluid films surround every mineral grain. We feel that $\delta_{f}=10^{-6} \mathrm{~cm}$ is probably a lower bound to film thickness, as this is $\sim 100$ interatomic spacings, and hence the fluid in any thinner film will no longer have the intrinsic transport properties of the bulk fluid. Thus a grain interstitial diffusion mechanism for the formation of eclogite from basalt or gabbro involves only a very small quantity of water, much less than that required to saturate the system.

The-time $t$ required to transport $S$ moles of a solute a distance $/$ through a tube of cross-sectional area $q$ is [Jost, 1960]

$$
t=S l / D q C_{0}
$$

where $C_{0}$ is the concentration of the diffusing species at the dissolving end of the tube and $D$ is the diffusion constant, assumed independent of concentration. We consider (15) as only an approximate relation since the fluid is undoubtedly dissolving ions such as $\mathrm{Mg}^{++}, \mathrm{Fe}^{++}, \mathrm{Al}^{+++}$, and $\mathrm{Ca}^{++}$with coordinated water molecules everywhere around the crystal. With $q=l \delta_{f},(15)$ becomes $t=S /\left(D C_{0} \delta_{f}\right)$. For complete transformation of $1 \mathrm{~cm}^{3}$ of basalt or gabbro to eclogite, $S=0.02 \mathrm{~mol}$ $\left(S \propto l^{3}\right)$. If some transportation under standard conditions is possible, the time scale $t$ may be calculated from (15) by using $D=10^{-4} \mathrm{~cm}^{2} / \mathrm{s}, \delta_{f}=10^{-8}-10^{-5} \mathrm{~cm}, C_{0}=10^{-8} \mathrm{~mol} / \mathrm{cm}^{3}$, and $S=0.02 \mathrm{~mol}$. These values yield about $10^{\circ}-10^{\circ} \mathrm{yr}$, which implies essentially no reaction on a tectonically meaningful time scale in agreement with geological observation. As will be discussed in the following section, the time scale can be markedly reduced, as $C_{0}$ is increased many orders of magnitude by increases in both pressure and temperature. We assume that the time required to dissolve the cations and establish the con- 
centration $C_{0}$ in the interstitial fluid is small, i.e., this time is not the rate-limiting step in the gabbro-eclogite reaction.

\section{Effect of Pressure and Temperature on Solubility aNd Diffusion of IONS}

To estimate the effect of pressure $p$ and temperature $T$ on the diffusion constant $D$ of ions in aqueous solution, we have assumed, following Jost [1960] and Walton [1960], that $D$ could be inferred from the viscosity of the fluid $\eta$ using the Stokes-Einstein equation

$$
D=\frac{R}{6 \pi N_{A} r_{\imath}} \frac{T}{\eta}
$$

where $R$ is the gas constant, $N_{A}$ is Avogadro's number, and $r_{i}$ is the effective radius of the diffusing ion. The use of (16) is, of course, necessitated by the lack of direct experimental measurement of $D$ at high pressures and temperatures, whereas data on the viscosity of water are available at pressures up to $1 \mathrm{kbar}$ over a wide range of temperature and even to $10 \mathrm{kbar}$ at temperatures below $100^{\circ} \mathrm{C}$. We assume that the concentration of the diffusing ions is sufficiently low not to affect the properties of the fluid.

The dependence of viscosity on temperature and pressure is shown in Figure 11. The solid portions of the curves are based on experimental data, while the dashed parts are extrapolations to higher pressures. Viscosity data for compressed water and superheated steam in the temperature range $0^{\circ}-700^{\circ} \mathrm{C}$ and for pressures between 1 and 800 bars are tabulated by Kestin and Dipippo [1972]. Measurements of viscosity of water for temperatures up to $900^{\circ} \mathrm{C}$ and pressures to $1 \mathrm{kbar}$ have been reported by Nagashima and Tanishita [1969]. Dudziak and Franck [1966] have measured water viscosities for pressures as high as $3.5 \mathrm{kbar}$ and temperatures up to $560^{\circ} \mathrm{C}$. Finally, Bett and Cappi [1965] presented viscosity values for compressed liquid at temperatures up to $100^{\circ} \mathrm{C}$ and pressures to $10 \mathrm{kbar}$. All these data have been included in Figure 11. The compressed liquid viscosities (for $T=100^{\circ}, 200^{\circ}$, and $300^{\circ} \mathrm{C}$ in Figure 11) were extrapolated to higher pressures by noting that the measured viscosity values for the temperatures of $100^{\circ}, 200^{\circ}$, and $300^{\circ} \mathrm{C}$ showed an essentially linear dependence on pressure. This linear dependence was assumed to apply at higher pressure for the viscosity curves at temperatures of $100^{\circ}, 200^{\circ}$, and $300^{\circ} \mathrm{C}$. For supercritical steam (temperatures $400^{\circ}-900^{\circ} \mathrm{C}$ in Figure 11), the viscosities were extrapolated to high pressure by assuming the validity of the correlation given by Kestin and Dipippo [1972]. This correlation is strictly applicable only for $375^{\circ} \mathrm{C}<T<700^{\circ} \mathrm{C}$ and 1 bar $<p<800$ bars. Use of the correlation required knowledge of the density of supercritical steam at the relevant pressures and temperatures [Kennedy, 1950; Rice and Walsh, 1957; Kennedy and Keeler, 1972].

Walton [1960] has noted that better agreement with experimental results is obtained if the $6 \pi$ in (16) is replaced by $4 \pi$. With this change, (16) may be rewritten as

$$
D r_{i}=\left(1.1 \times 10^{-17} \mathrm{erg} /{ }^{\circ} \mathrm{K}\right) T / \eta
$$

Figure 12 shows the product $D r_{l}$ obtained from (17) and the data of Figure 11 as a function of pressure with temperature as a parameter. This is a useful intermediate step since the diflusion coefficient for different ions is then readily obtainable. Since $r_{l}$ is of the order of an angstrom unit, the diffusion coefficients of various cations will vary between about $10^{-3}$ and $10^{-4}$ $\mathrm{cm}^{2} / \mathrm{s}$ over a wide range of geologic conditions, a conclusion already reached by Walton [1960]. As can be seen from Figure 12 , the diffusion constant characteristic of supercritical water

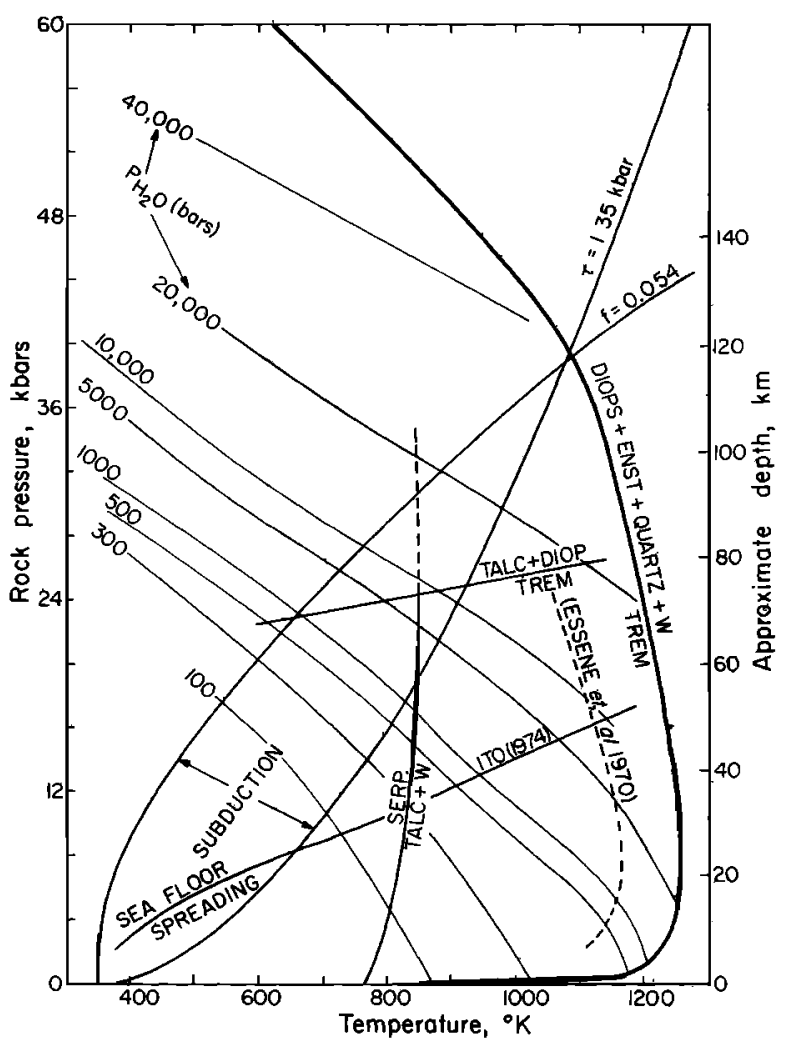

Fig. 9. Vapor pressure of $\mathrm{H}_{2} \mathrm{O}$ associated with pure tremolite for spontaneous dehydration, according to reaction (10), as a function of temperature and total pressure. Possible thermodynamic paths for the top of the subducting lithosphere are shown as lines of constant $\tau$ and $f$ [Turcotte and Schubert, 1973].

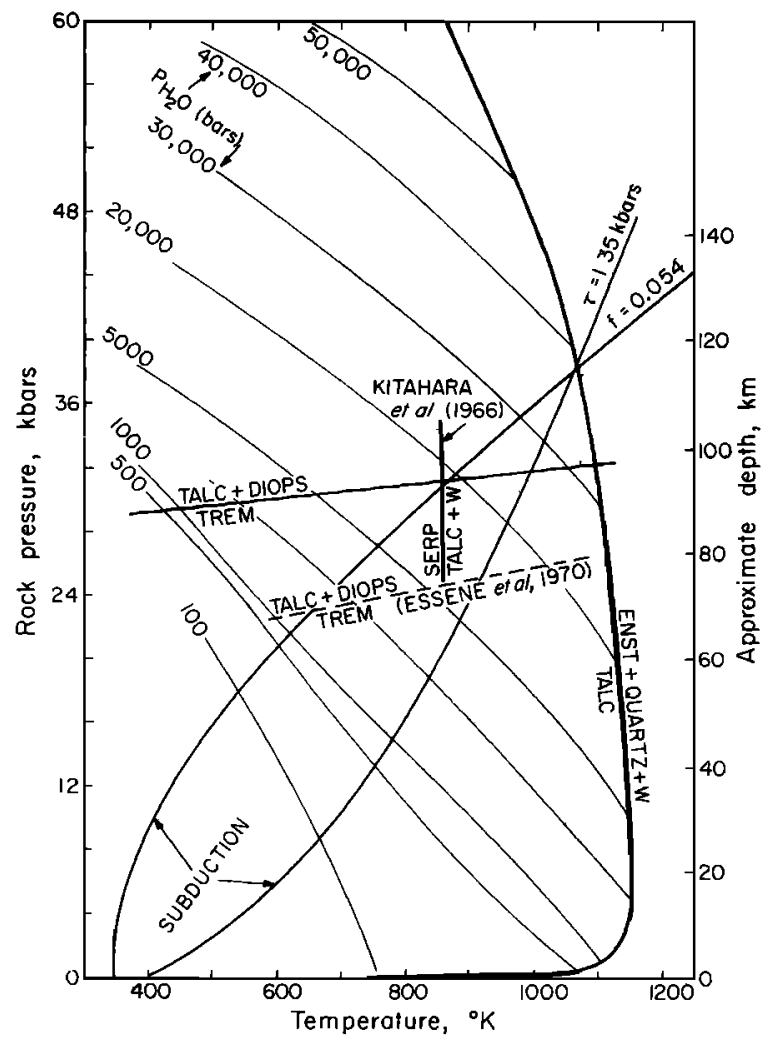

Fig. 10. Vapor pressure of $\mathrm{H}_{2} \mathrm{O}$ associated with pure talc for spontaneous dehydration, according to reaction (11), as a function of total pressure. Possible thermodynamic paths for the top of the subducting lithosphere are shown as lines of constant $\tau$ and $f$ [Turcotte and Schubert, 1973]. 


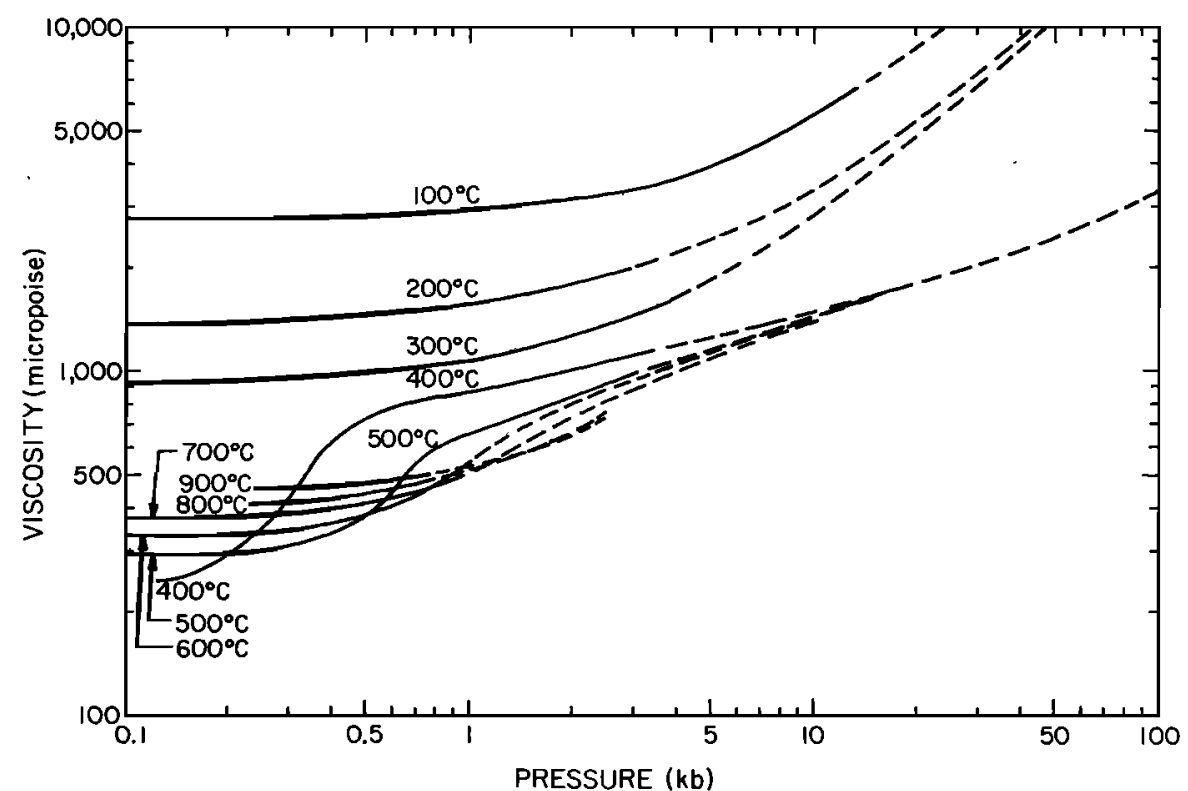

Fig. 11. Experimental viscosity data (solid portions of curves) for compressed liquid and superheated steam as a function of pressure $p$ with temperature $T$ as a parameter. Extrapolations to higher pressures are indicated by dashed parts of the curves. Data were obtained from Kestin and Dipippo [1972], Nagashima and Tanishita [1969], Dudziak and Franck [1966], and Bett and Cappi [1965].

above $400^{\circ} \mathrm{C}$ may vary even less than an order of magnitude, from a depth of perhaps $3 \mathrm{~km}$ to several hundred kilometers in the mantle. Effective ionic radii for cations in hydrothermal solution are typically in the range $2 \AA$ for $\mathrm{Na}^{+}$to $\sim 4.5 \AA$ for $\mathrm{Al}^{\mathrm{a}+}$ [Garrels and Christ, 1965].

In contrast to the effective diffusion constant, although pertinent data are less abundant, the concentration of the diffusing species in supercritical water is strongly dependent on pressure and to a lesser degree on temperature. This effect, which strongly controls grain interstitial diffusion and hence transformation of gabbro to eclogite in the lower crust and upper mantle, has not been previously recognized. The data of Morey and Hesselgesser [1951] and Kennedy et al. [1962] for

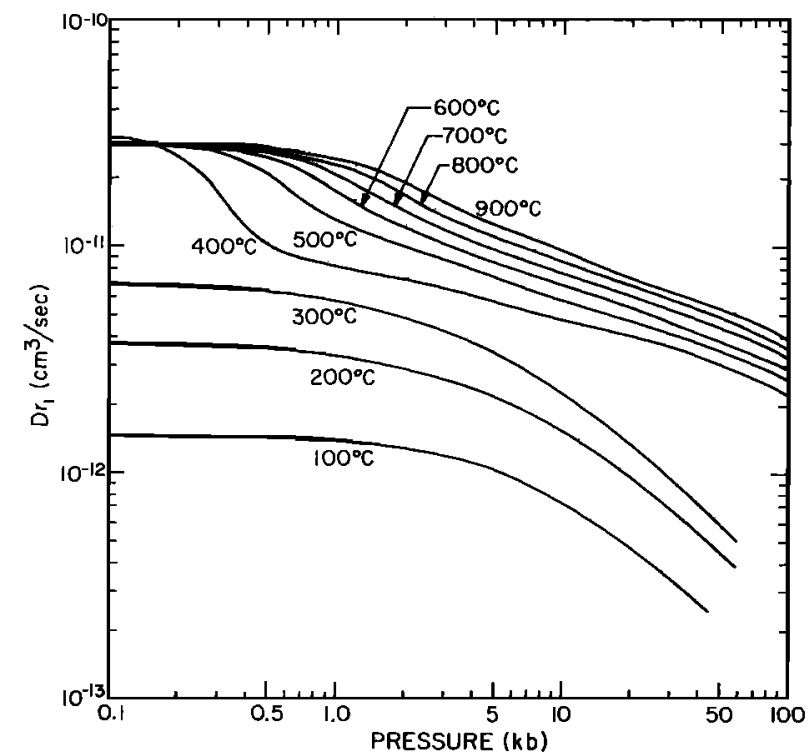

Fig. 12. The product of diffusion constant $D$ and ionic radius $r_{i}$ for ions diffusing through compressed liquid and superheated steam as a function of pressure at various temperatures. The dependence of $D r_{t}$ on temperature and pressure has been determined from the StokesEinstein relation between $D r_{1}$ and viscosity and the dependence of viscosity on temperature and pressure (Figure 11). the amount of the equivalent oxide dissolved in supercritical water are summarized in Figure 13. These data should represent an upper bound to the ion concentration (we have not attempted to calculate the appropriate aqueous dissociation reactions, although in principle it is possible to do so [Helgeson and Kirkham, 1974]). It can be seen that silica, either from $\mathrm{SiO}_{2}$ crystal or from feldspar or pyroxene, is about an order of magnitude more soluble than the other oxides. The single datum for the solubility of $\mathrm{Al}_{2} \mathrm{O}_{3}$ (corundum) suggests that this oxide is less soluble in pure form than when the source is a feldspar, probably because of the lack of highly ionic readily soluble associated cations. When extrapolated to 1 bar, these data are not inconsistent with the very low solubilities under standard conditions inferred in the previous section. The data of Figure 13 indicate a negligible dependence of solubility on temperature; they also suggest a power law dependence of solubility on pressure. The relation

$$
C_{0}(\mathrm{~mol} / \mathrm{l})=2.38 \times 10^{-12}(p(\text { bars }))^{2.7}
$$

should be approximately valid for the concentration of ions in equilibrium with feldspars and pyroxenes (and presumably also olivine) in the $1-30 \mathrm{kbar}$ and $300^{\circ}-1000^{\circ} \mathrm{C}$ range.

Finally, the gabbro-eclogite reaction time as a function of temperature and pressure, based on the grain interstitial diffusion model, can be calculated from (15), (17), (18), and Figure 11 with $q=l \delta, S=0.02 \mathrm{~mol}, \delta_{f}=10^{-5}$ and $10^{-6} \mathrm{~cm}$, and $r_{t}=$ $0.5 \AA$. Figure 14 shows the resultant partial pressure of water required to achieve transformation as a function of reaction time. The $\mathrm{H}_{2} \mathrm{O}$ partial pressures accompanying traces of various hydrous minerals contained in or associated with basalts and gabbros, which were calculated in the preceding section, are applied to the reaction rate problem in a later section.

\section{EFFect of $\mathrm{CO}_{2}$ ON Solubility AND Phase Equilibria}

In this section we summarize the available data on the solubility of various cations in high pressure and high temperature $\mathrm{H}_{2} \mathrm{O}-\mathrm{CO}_{2}$ mixtures and on the influence of $\mathrm{CO}_{2}$ 


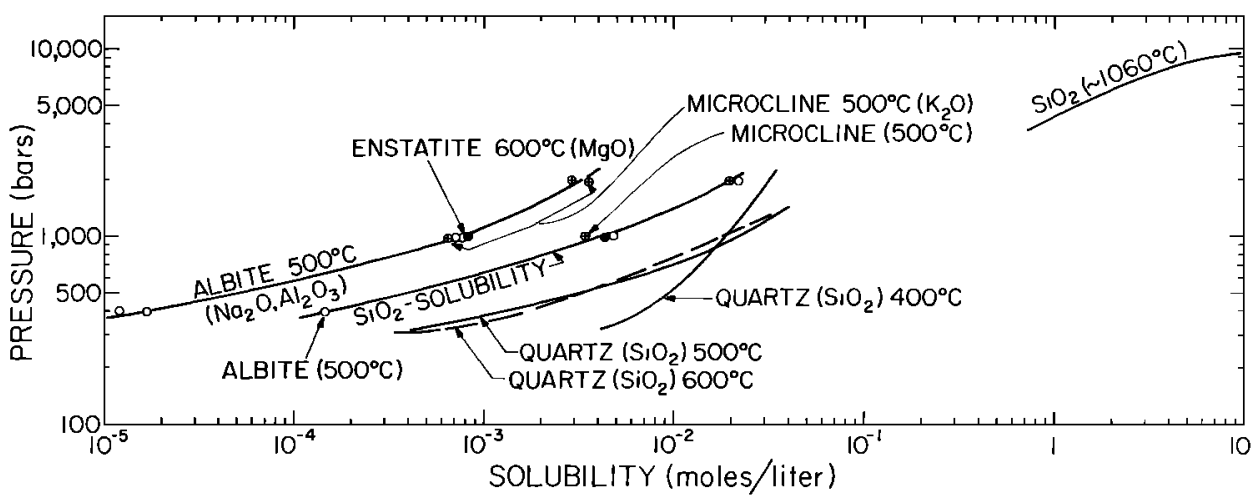

Fig. 13. Measured values of the solubility of a number of minerals in superheated steam at various pressures and temperatures. The solubility is strongly pressure-dependent and relatively insensitive to temperature. Data are from Morey and Hesselgesser [1951] and Kennedy et al. [1962].

on different mineral system phase equilibria. Table 5, from Morey [1957], shows that the addition of a small amount of $\mathrm{CO}_{2}$ to superheated steam at $500^{\circ} \mathrm{C}$ and $1 \mathrm{kbar}$ significantly increases the solubility of iron and tin oxides and $\mathrm{CaCO}_{3}$ while it decreases the solubility of quartz. Burnham [1967] reported on the effects of 2 and $5 \mathrm{wt} \% \mathrm{CO}_{2}$ solutions on the composition of the aqueous phase in equilibrium with granite at $650^{\circ} \mathrm{C}$ and $6.0 \mathrm{kbar}$. The total solute content was considerably reduced below that in distilled water at the same temperature and pressure; the reduction in solute content was proportional to the percentage of $\mathrm{CO}_{2}$. For the $5 \% \mathrm{CO}_{2}$ mixture the ratio of the concentration of $\mathrm{Si}$ to the concentration of $\mathrm{Si}$ in the pure aqueous phase was 0.55 . A similar concentration reduction ratio for $\mathrm{Al}$ was 0.49 , for $\mathrm{K}$ it was 0.28 , and for $\mathrm{Na}$ it was 0.25 . Calcium content in the $5 \% \mathrm{CO}_{2}$ mixture as compared with that in the pure $\mathrm{H}_{2} \mathrm{O}$ phase was reduced even more than the $\mathrm{Na}$ content. Burnham [1967] pointed out that the effects of $\mathrm{CO}_{2}$ on the solubilities of the alkalies $\mathrm{K}$ and $\mathrm{Na}$ as compared with the solubilities of $\mathrm{Si}$ and $\mathrm{Al}$ were consistent with the element distributions in contact metasomatic aureoles.

Shettel [1973] has published the most complete information on the solubility of quartz in $\mathrm{H}_{2} \mathrm{O}-\mathrm{CO}_{2}$ mixtures at $5 \mathrm{kbar}$ and $500^{\circ}-900^{\circ} \mathrm{C}$. Decreasing the fugacity of $\mathrm{H}_{2} \mathrm{O}$ by dilution with

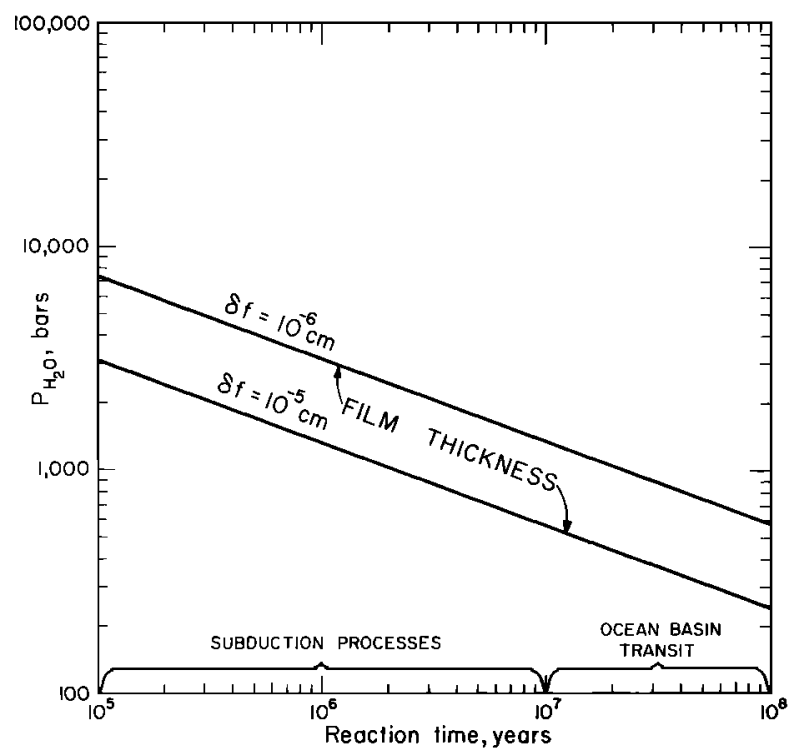

Fig. 14. Time scales for the gabbro-eclogite transition as a function of $P_{\mathrm{H}_{2} \mathrm{O}}$ according to the grain interstitial diffusion model. Equation (15), with values of $D=10^{-4} \mathrm{~cm}^{2} / \mathrm{s}, S=0.02 \mathrm{~mol}$, and $C_{0}$ given by (18), is used to construct the diagram.
$\mathrm{CO}_{2}$ exponentially decreases the $\mathrm{Si}$ solubility, a result of the value of the hydration number $n$ in the reaction $\mathrm{SiO}_{2}+n \mathrm{H}_{2} \mathrm{O}$ $\rightarrow \mathrm{SiO}_{2} \cdot n \mathrm{H}_{2} \mathrm{O}$. Values of $n$ are $4.9,4.4$, and 4.5 at temperatures of $500^{\circ}, 700^{\circ}$, and $900^{\circ} \mathrm{C}$, respectively. At $700^{\circ} \mathrm{C}$ the solubility of $\mathrm{SiO}_{2}$ is $2.35 \mathrm{wt} \%$ for pure $\mathrm{H}_{2} \mathrm{O}, 0.5 \mathrm{wt} \%$ for $X_{\mathrm{H}_{2} \mathrm{O}}=0.75$, and $0.1 \mathrm{wt} \%$ for $X_{\mathrm{H}_{2} \mathrm{O}}=0.5$ [Shettel, 1973].

The compositions of fluid phase solutes in a basalt-watercarbon dioxide system consisting of $50 \mathrm{wt} \%$ of 1921 Kilauea basalt, $16 \% \mathrm{H}_{2} \mathrm{O}$, and $34 \% \mathrm{CO}_{2}$ have been given by Holloway [1971] for temperatures of $800^{\circ}, 900^{\circ}, 1000^{\circ}$, and $1100^{\circ} \mathrm{C}$. The total solute content was small, ranging from 0.5 to $2 \mathrm{wt} \%$, the solute content tending to be proportional to fluid density and thus tending to decrease with increasing temperature and to increase with increasing pressure. $\mathrm{SiO}_{2}, \mathrm{Al}_{2} \mathrm{O}_{3}$, and $\mathrm{MgO}$ constituted most of the solute, other oxides such as $\mathrm{CaO}$, $\mathrm{Na}_{2} \mathrm{O}$, and $\mathrm{TiO}_{2}$ also being present.

In addition to the influence of $\mathrm{CO}_{2}$ on mineral solubility in superheated steam, the effect of $\mathrm{CO}_{2}$ on the phase equilibria of minerals is clearly an important one for our study of the basalt-eclogite reaction. Hill and Boettcher [1970] have determined the solidus curves for basalt- $\mathrm{H}_{2} \mathrm{O}$ and basalt- $\mathrm{H}_{2} \mathrm{O}-\mathrm{CO}_{2}$ mixtures at pressures up to $30 \mathrm{kbar}$ (Figure 15). The basalt$\mathrm{H}_{2} \mathrm{O}$ system contained $15 \% \mathrm{H}_{2} \mathrm{O}$ by weight, while the mixture with $\mathrm{CO}_{2}$ had $50 \mathrm{~mol} \%$ each of $\mathrm{CO}_{2}$ and $\mathrm{H}_{2} \mathrm{O}$. Below $15 \mathrm{kbar}$ the presence of $\mathrm{CO}_{2}$ raises the solidus temperature as much as $100^{\circ} \mathrm{C}$, while above this pressure the influence of $\mathrm{CO}_{2}$ on solidus temperature is insignificant. Hill and Boettcher [1970] also demonstrated that plagioclase is stabilized at high pressure in the presence of $\mathrm{CO}_{2}$. Above about $10 \mathrm{kbar}$, amphibole stability is also increased in the presence of $\mathrm{CO}_{2}$ as a result of the reduction in $\mathrm{H}_{2} \mathrm{O}$ activity with the addition of $\mathrm{CO}_{2} . \mathrm{Hol}$ loway and Burnham [1972] have also investigated the solidus and upper stabilities of plagioclase and amphibole in a basalt$\mathrm{H}_{2} \mathrm{O}-\mathrm{CO}_{2}$ system containing about $36 \mathrm{wt} \% \mathrm{H}_{2} \mathrm{O}$ and $64 \mathrm{wt} \%$ $\mathrm{CO}_{2}$ in the fluid phase at pressures of 2,5 , and $8 \mathrm{kbar}$ and temperatures between $800^{\circ}$ and $1100^{\circ} \mathrm{C}$. In comparison with the properties of a basalt- $\mathrm{H}_{2} \mathrm{O}$ mixture, it was found that the

TABLE 5. Solubilities in Parts per Million in Superheated Steam With About $7 \% \mathrm{CO}_{2}$ at $500^{\circ} \mathrm{C}$ and 1 Kilobar [After Morey, 1957]

\begin{tabular}{lcc}
\hline & Without $\mathrm{CO}_{2}$ & With $\mathrm{CO}_{2}$ \\
\hline $\mathrm{CaCO}_{3}$ & 120 & 940 \\
$\mathrm{Fe}_{2} \mathrm{O}_{3}$ & 80 & 230 \\
$\mathrm{NiO}_{\mathrm{SnO}}$ & 20 & 43 \\
$\mathrm{Quartz}$ & 2 & 50 \\
& 26,000 & 19,000 \\
\hline
\end{tabular}




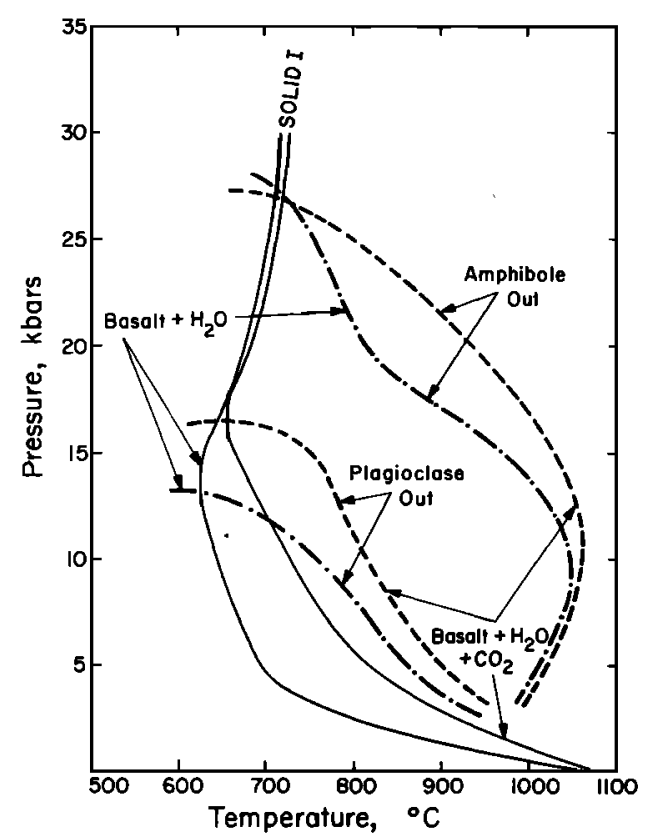

Fig. 15. Effect of $\mathrm{CO}_{2}$ on approximate phase diagram of vapor saturated basalt-water-carbon dioxide compositions [Hill and Boettcher, 1970].

solidus temperature and upper stability temperature of plagioclase were increased by about $100^{\circ} \mathrm{C}$ and the decomposition temperature of amphibole was increased by about $60^{\circ} \mathrm{C}$.

For a peridotite $\left(\mathrm{SiO}_{2}\right.$ wt \% 43.7-45.7, $\mathrm{Al}_{2} \mathrm{O}_{3}$ wt \% 1.6-8.2, $\mathrm{CaO}$ wt $\%$ 0.7-8.1)- $\mathrm{H}_{2} \mathrm{O}-\mathrm{CO}_{2}$ system, Mysen and Boettcher [1973] have studied the stability of amphibole at pressures from 7.5 to $30 \mathrm{kbar}$ and for $\boldsymbol{X}_{\mathrm{H}_{2} \mathrm{O}}$ (mole fraction) between 0.25 and 1.0. Amphibole was stable up to temperatures of $1080^{\circ}$, $1100^{\circ}, 950^{\circ}$, and $760^{\circ} \mathrm{C}$ at pressures of $7.5,13,23.5$, and 20 kbar, respectively. Changing $X_{\mathrm{H}_{2} \mathrm{O}}$ from 1.0 to 0.25 did not significantly affect the amphibole stability.

We conclude from the foregoing that although the presence of $\mathrm{CO}_{2}$ modifies the phase diagrams and affects the ion solubility in superheated steam, the major role of $\mathrm{CO}_{2}$ is to provide an additional fluid partial pressure so that water vapor may be present in undersaturated rock interstices.

\section{Application of the Grain Interstitial DifFusion Model to SUBdUCTION}

We assume in the following that basaltic composition rocks of the uppermost lithosphere comprising the basement rock of the ocean floor are subducted and are in the process exposed to a thermodynamic path similar to the paths computed by Turcotte and Schubert [1973] and Toksöz et al. [1971]. The question as to how deep basaltic-type composition rocks extend into the mantle portion of the lithosphere, i.e., depths greater than $\sim 12 \mathrm{~km}$, in the form of granulite, or eclogite, has been the subject of several recent studies [Forsyth and Press, 1971; Ito, 1974] and remains to be definitively settled. However, there appears to be little doubt that the uppermost igneous rocks are basaltic. If, as we believe is likely, these rocks are undersaturated with respect to $\mathrm{H}_{2} \mathrm{O}$, we can apply the $\mathrm{H}_{2} \mathrm{O}$ vapor pressure calculation for serpentine (assuming a similarity to chlorite), tremolite, and talc to give lower bounds on the time scale for the gabbro-eclogite transformation. In general, the presence of other major phases, and possibly extra but not excess water, will only tend to increase the vapor pressure and hence give faster reaction times. By only considering the above three minerals we are tacitly assuming that the system contains sufficient water to have formed all the possible very low vapor pressure minerals such as phlogopite. We suspect that the breakdown reactions of such minerals as phlogopite and possibly titanoclinohumite will buffer the $\mathrm{H}_{2} \mathrm{O}$ partial pressure at temperatures greater than $\sim 1100^{\circ} \mathrm{C}$ and pressures of $\sim 100$ kbar, probably below regions in the subducting slab where both the gabbro-eclogite transition and possibly partial melting [Turcotte and Schubert, 1973] are occurring.

For rocks which are predominantly composed of olivine and plagioclase, with some chlorite representing the hydrous phase, Figure 8 demonstrates that upon subduction the minimum $\mathrm{H}_{2} \mathrm{O}$ vapor pressure will be quite high. Along the constant shear $\tau$ and constant coefficient of friction $f$ curves, vapor pressures of 1000 bars will be induced at depths of only 15 and $30 \mathrm{~km}$, respectively. For $10^{-5}$ - and $10^{-\theta}-\mathrm{cm}$-thick films on the grains, vapor phase assisted diffusion can produce the gabbro-eclogite phase change on a time scale of $\sim 2$ and $\sim 20$ m.y., respectively. Vapor pressures of $2 \mathrm{kbar}$ corresponding to reaction times of $300,000 \mathrm{yr}$ to $3 \mathrm{~m}$.y. are achieved at depths of $\sim 15$ and $\sim 35 \mathrm{~km}$ for constant shear stress and constant friction coefficient models, respectively. Hence in a predominantly olivine-rich assemblage containing some water at temperatures below the high-pressure dehydration temperature of serpentine or chlorite, $\sim 450^{\circ} \mathrm{C}\left(\sim 775^{\circ} \mathrm{K}\right)$, the gabbro-eclogite transition, at least as far as the olivine components are concerned, will occur readily. At temperatures above the serpentine dehydration temperature, even more water will be available, and the system may behave like the saturated system (Figure 7) if sufficient pyroxenes are unavailable to form amphiboles. For the more usual pyroxene-rich assemblages, serpentine or chlorite dehydrates in favor of amphibole, and the vapor pressure in the rock will probably be controlled by amphibole (here modeled by tremolite, if sufficient $\mathrm{Ca}^{++}$is present). In this case tremolite, or some similar mineral, controls the minimum vapor pressure until it breaks down in favor of such minerals as talc and diopside. (The vapor pressure in equilibrium with talc is virtually the same as that in equilibrium with tremolite.) In this case, 1000 bars' of water pressure is inferred to occur at depths of about 70 and 50 $\mathrm{km}$, respectively, along the constant friction and constant shear stress paths. We recall that the characteristic reaction times are 2 and $20 \mathrm{~m} . y$., respectively, for films $10^{-6}$ and $10^{-8}$ $\mathrm{cm}$ thick. Again as in the case of serpentine- or chloritecontrolled $\boldsymbol{P}_{\mathrm{H}_{2} \mathrm{O}}$, these total pressures are well within the stability field of eclogite in a 'dry' system; however, the pressures required are comparable to the 15-20 kbar required to produce eclogite from a garnet amphibolite in a totally saturated system.

Approximate contours of constant reaction time for the upper $200 \mathrm{~km}$ of the mantle in the region of a descending slab are shown in Figure 16 for serpentine and tremolite, or talc, buffered $\mathrm{H}_{2} \mathrm{O}$ vapor pressures. The temperature distribution given in Figure 16 is based on the calculations of Turcotte and Schubert [1973] and Schubert et al. [1974] for an angle of dip of $45^{\circ}$ and a velocity of the plate approaching the trench equal to $8 \mathrm{~cm} / \mathrm{yr}$. Frictional heating on the upper surface of the descending slab raises the temperature along the slip zone until an assumed melt temperature of $1000^{\circ} \mathrm{C}$ is reached. The shear stress heating occurs under a constant coefficient of friction $f$ $=0.054$. The volcanic line is located directly above the point on the slip zone where melting first occurs. Behind the volcanic line beneath the region of anomalously high heat flow the temperature on the slip zone is buffered at the melt 

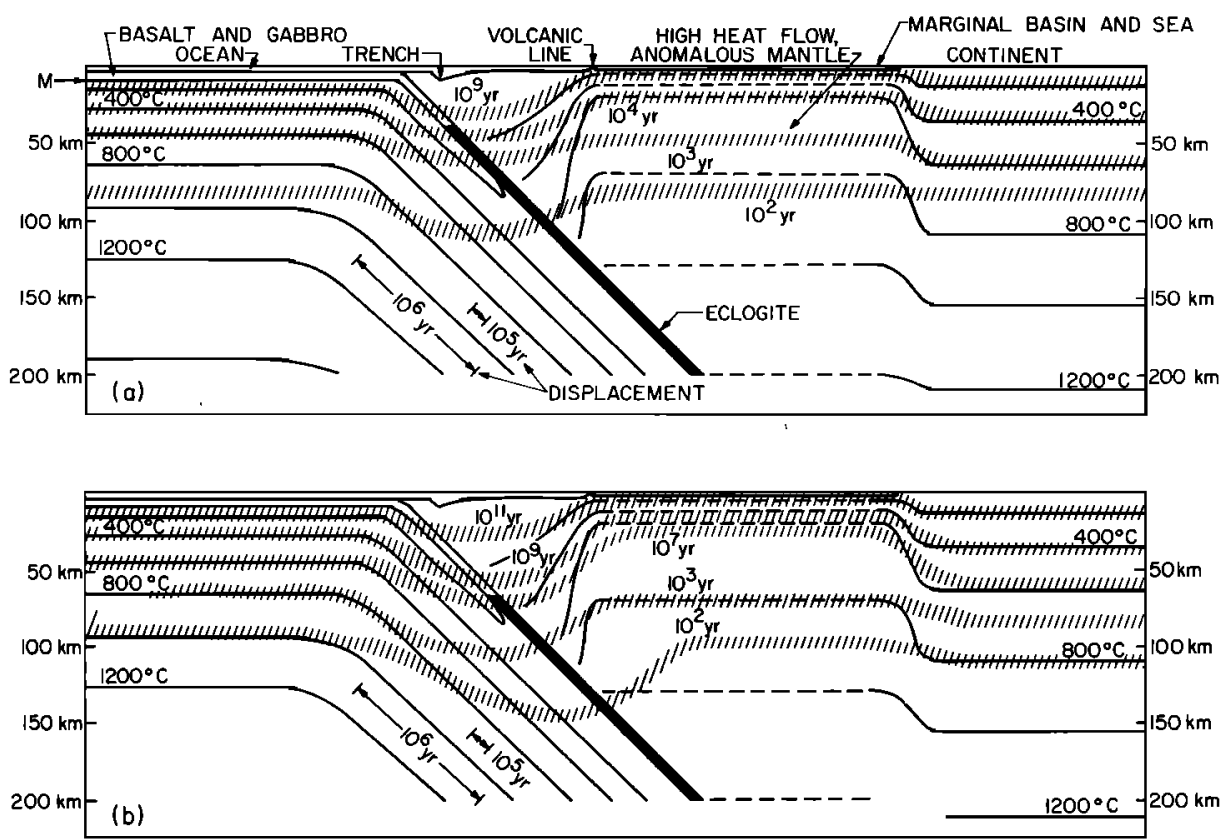

Fig. 16. Approximate contours of constant reaction time for the gabbro-eclogite phase change in a thermal model [Turcotte and Schubert. 1973; Schubert et al., 1974] of the downgoing slab and the surrounding mantle with $\mathrm{H}_{2} \mathrm{O}$ partial pressure buffered by $(a)$ serpentine and $(b)$ talc or tremolite.

temperature, which increases with pressure. The dashed isotherms above the descending slab in this region are only estimates of the temperature, since processes such as magma transport of heat may significantly influence the thermal structure. The continental geotherm is from Froidevaux and Schubert [1975], and the oceanic geotherm is from Turcotte and Oxburgh [1969].

Since the temperatures and pressures in the model of Figure 16 are completely known, the $\mathrm{H}_{2} \mathrm{O}$ vapor partial pressure at any point in the mantle can be determined from Figure 8 for a serpentine- or chlorite-buffered system and from Figures 9 or 10 for a tremolite- or talc-controlled $\mathrm{H}_{2} \mathrm{O}$ vapor pressure. For pressures and temperatures sufficiently high for dehydration of any of these minerals, we assume that $\boldsymbol{P}_{\mathrm{H}_{2} \mathrm{O}}=\boldsymbol{P}_{\text {total }}$ is the lithostatic pressure. Figure 14, with an assumed film thickness of $10^{-5} \mathrm{~cm}$ then yields the reaction times shown approximately by the hatched contours of Figure 16. In the serpentine- or chlorite-buffered situation for a gabbroic oceanic crust the grain interstitial model predicts change to eclogite at depths of around $30 \mathrm{~km}$. In contrast, a depth of about $70 \mathrm{~km}$ is required for transformation of the oceanic gabbroic crust to eclogite in the talc- or tremolite-buffered system. If basalt or gabbro exists in the suboceanic lithosphere beneath the crust, it will transform to eclogite at depths indicated by the reaction time contours of Figure 16 according to our diffusion model.

The net gravitational body force on the descending slab is an important part of the driving force for plate motions [McKenzie, 1969]. Schubert and Turcotte [1971] and Griggs [1972] have discussed the downward body forces due to thermal contraction of the slab and the elevation of the olivine-spinel phase boundary; the force due to the olivine-spinel transition was estimated to be about a third of that due to thermal contraction [Turcotte and Schubert, 1971]. The gabbro-eclogite transition, even if confined only to the oceanic crust, also contributes importantly to the net downward body force on the slab. The downward body force per unit distance parallel to the trench and per unit depth, associated with the formation of eclogite, is $\Delta \rho \cdot g \cdot\left(t_{c} / \sin \theta\right)$, where $\Delta \rho$ is the density of eclogite minus the density of the surrounding mantle, $t_{c}$ is the crustal thickness, and $\theta$ is the angle of dip. With $\Delta \rho=3.5-3.3 \mathrm{~g} / \mathrm{cm}^{3}, t_{c}=5-10$ $\mathrm{km}$, and $\theta=45^{\circ}$, we find this gabbro-eclogite phase change associated body force per unit depth and trench length is about 0.2 kbar. Schubert et al. [1974] find about $0.5 \mathrm{kbar}$ for the body force 'density' associated with thermal contraction. If the oceanic crust transforms to eclogite at a depth of $50 \mathrm{~km}$ in the descending slab, then the total downward body force per unit length of trench due to an eclogite crust extending down to $400-\mathrm{km}$ depth is about $0.7 \times 10^{18} \mathrm{dyn} / \mathrm{cm}$. This is to be compared with the total downward body force per unit length of trench of about $10^{16} \mathrm{dyn} / \mathrm{cm}$ associated with the elevation of the $400-\mathrm{km}$ olivine-spinel phase change in the descending slab, the downward body force of thermal contraction in the slab to a depth of $400 \mathrm{~km}$ of about $2 \times 10^{18} \mathrm{dyn} / \mathrm{cm}$, and the upward body force associated with the hypothetical depression of the $650-\mathrm{km}$ spinel-oxide transition of approximately $0.3 \times 10^{18} \mathrm{dyn} / \mathrm{cm}$ [Schubert et al., 1974].

\section{Summary AND ConClusions}

Our major objectives have been to estimate the reaction rate of the gabbro-eclogite phase change and to delineate where the reaction may occur in the basalts and gabbros of the oceanic crust upon subduction beneath island arcs and in any initial gabbroic constituent of the upper $\sim 100 \mathrm{~km}$ of the oceanic lithosphere as it moves away from a ridge. In the case of transformation of the basaltic and gabbroic oceanic crust to eclogite upon subduction [Ringwood and Green, 1966; Schubert and Turcotte, 1972], times of the order of $10^{5}-10^{6} \mathrm{yr}$ are of interest since these correspond to distances along the slab of $\sim 10-100 \mathrm{~km}$ for typical subduction rates. For the transformation of a possible gabbroic constituent of the oceanic lithosphere as it spreads from a ridge [Press, 1969; Forsyth and Press, 1971], the pertinent time scale is $10^{7}-10^{\mathrm{a}}$ yr. The smaller value corresponds to the approximate time required to produce the increase in lithospheric seismic velocity with distance from a spreading ridge, as observed at the $\sim 50 \mathrm{~m}$.y. line in the North Atlantic [Hart and Press, 1973]. The $10^{8}$ yr value 
is the approximate time required for an ocean basin transit of the moving suboceanic lithosphere.

On the basis of the laboratory diffusion data for oxides and silicates, we have examined the range of possible reaction times for transformation of gabbro to eclogite via the mechanism of solid state volume diffusion of cations such as $\mathrm{Al}^{+++}, \mathrm{Fe}^{++}, \mathrm{Mg}^{++}$, and $\mathrm{Ca}^{++}$. We conclude that the effective multicomponent diffusion constant is probably within an order of magnitude of the slowest moving species, which within garnet we infer to be $\mathrm{Al}^{+++}$. Our results imply that formation of $0.1-1 \mathrm{~cm}$ crystals of garnet by solid state diffusion below $600^{\circ} \mathrm{C}$ in the upper $100 \mathrm{~km}$ of the subducting or spreading oceanic lithosphere is impossible on the time scales of interest. Considerable indirect evidence demonstrating that solid state diffusion disequilibrium in garnets can be maintained under metamorphic conditions for millions of years also stems from the typically gross variation in chemistry observed within a single garnet crystal from these environments [Dudley, 1969; Graham and Ahrens, 1973].

Upon considering the implications of the presence of interstitial superheated steam in the suboceanic crust and lithosphere, even in a quantity as small as $10^{-6}$ mass fraction, we conclude that eclogite can form relatively rapidly via the mechanism of interstitial diffusion. Evidence for the existence of water vapor in the suboceanic lithosphere stems from the chlorite- and amphibole-bearing igneous rocks which have been dredged from the ocean floor. Presumably a small fraction of the water is interstitial and probably at a lower pressure than that of the rock, being in vapor equilibrium with the minerals.

In the interstitial diffusion process, we envision ions such as $\mathrm{Al}^{+++}, \mathrm{Fe}^{++}, \mathrm{Ca}^{++}, \mathrm{Mn}^{++}, \mathrm{Cr}^{+++}, \mathrm{Fe}^{+++}$and $\mathrm{HSiO}_{4}^{-}$ produced in the interstitial fluid upon solution of such minerals as olivine, pyroxene, plagioclase, and spinel. Upon transport of these ions through a layer of superheated steam, which can probably be as thin as $10^{2} \AA$, deposition at sites of garnet crystallization occurs. We infer that although $\mathrm{SiO}_{2}$ is more readily soluble in superheated steam than such oxides as $\mathrm{Al}_{2} \mathrm{O}_{3}$ and $\mathrm{MgO}$, its transport is less important, as garnet will probably form upon minor rearrangement of $\mathrm{SiO}_{4}=$ tetrahedra at sites of other minerals.

For the interstitial diffusion process, the time constant for complete reaction of gabbro to eclogite will in general depend upon the grain size of the minerals in the rock, the partial pressure of water, the diffusion constant of ions in the fluid, and the concentration of the ions in solution at the point in the fluid where these go into solution. Although we have explicitly taken into account the (relatively minor) variations of viscosity and hence the diffusion constant with pressure and temperature, both the increase of solubility with pressure in superheated steam and the partial pressure of $\mathrm{H}_{2} \mathrm{O}$ which is available for ion transport turn out to be the two controlling parameters for interstitial diffusion rates. We infer from the limited pertinent solution data that once the temperature and pressure of the water triple point are achieved, temperature has only a minor effect on silicate solubility. The relatively large increase in the solubility of silicates with pressure could in principle be predicted on the basis of the marked increase with pressure in ionic electrical conductivity in water and $\mathrm{D}_{2} \mathrm{O}$ [Hamann and Linton, 1966]. These authors have demonstrated that this arises from the large increase in the self-ionization of water with increasing pressure (in essence, the water acts as a strong acid at high pressure).

Turcotte and Schubert [1973] have shown that the frictional heating of the subducting oceanic lithosphere at trenches would produce an increase of temperature $\Delta T$ in time $\Delta t$ for material at the top of the oceanic crust given by

$$
\Delta T=2 u(k \Delta t / \pi)^{1 / 2} \tau / k
$$

where $x$ is the thermal diffusivity, $k$ is the thermal conductivity, $u$ is the velocity of the subducting plate, and $\tau$ is the assumed constant shear stress acting along the top of the subducting crust. This increase of temperature with depth (or pressure) is shown in Figures 8-10 for a subduction angle of $45^{\circ}, u=8$ $\mathrm{cm} / \mathrm{yr}, \kappa=1.15 \times 10^{-2} \mathrm{~cm}^{2} / \mathrm{s}, k=10^{-2} \mathrm{cal} / \mathrm{cm} \mathrm{s}^{\circ} \mathrm{K}$, and $\tau=$ $1.35 \mathrm{kbar}$. Also shown is the increase in temperature calculated under the assumption that the coefficient of friction along the shear zone is a constant $(f=0.054)$. By assuming that these temperature-pressure paths are typical of those to which oceanic lithosphere containing an uppermost gabbro composition layer is exposed upon subduction, it is possible to estimate the time scale required to complete the gabbro-eclogite transition for olivine- or pyroxene-rich rocks. By applying Figure 14 to infer the time required for transformation, we conclude that for chlorite-rich rocks with $10^{-5}$-cm-thick grain boundaries, vapor phase assisted diffusion can occur on a time scale of $\sim 2$ m.y. at depths of only $\sim 15$ and $\sim 30 \mathrm{~km}$, respectively, for constant shear stress $(\tau=1.35 \mathrm{kbar})$ and constant friction coefficient $(f=0.054)$ models. The temperatures of the reaction are extremely low for these models, only $150^{\circ}$ and $300^{\circ} \mathrm{C}$, respectively. For rocks which are pyroxene-rich, where the vapor pressure is buffered by the formation of amphibole, with tremolite (or talc) as a model, complete reaction of gabbro to eclogite, the phase diagram for the dry system being assumed, is calculated to occur at depths of 50 and $70 \mathrm{~km}$ for the two assumed thermodynamic paths. The reaction time is again $\sim 2$ m.y. The temperatures achieved upon complete reaction, $400^{\circ}$ and $550^{\circ} \mathrm{C}$, although higher than those of chlorite-buffered rocks, are still lower than the temperatures $\left(>600^{\circ} \mathrm{C}\right)$ required of the solid state diffusion model. We note however that in the case of a tremolite-buffered $\mathrm{H}_{2} \mathrm{O}$ system, the predicted depths for the gabbro-eclogite phase change imply pressures comparable to the considerable range of transformation pressures observed for garnet amphibolite transforming to eclogite in the water-saturated basalts studied by Essene et al. [1970] and Allen et al. [1972]. The above ranges of temperature $\left(\sim 150^{\circ}-\right.$ $550^{\circ} \mathrm{C}$ ) are similar to the low crystallization temperatures inferred by Taylor and Coleman [1968] for the glaucophanebearing rocks of the California Franciscan formation, which presumably formed upon subduction of the Mesozoic lithosphere.

Finally, we examine the possible time scales for the transformation of initially hot basalt or gabbro to garnet granulite or eclogite within the oceanic lithosphere. From Figure 14 we infer that $\mathrm{H}_{2} \mathrm{O}$ vapor pressures greater than $\sim 600$ and $\sim 1500$ bars (depending on grain boundary thicknesses) are required to transform gabbro to eclogite on a time scale of $\sim 10$ m.y. Using the steady state pressure-temperature profile of Ito [1974], which essentially implies horizontal flow streamlines, we conclude from Figure 8 that such vapor pressures are always achieved at greater temperatures than those required for the dehydration of chlorite or serpentine. Hence we infer that the $\mathrm{H}_{2} \mathrm{O}$ vapor pressure in the lower 'steady state oceanic' lithosphere (below $33 \mathrm{~km}$ ) is probably buffered by equilibrium with amphibole. If the minimum vapor pressure associated with tremolite can be used as a measure of the in situ vapor pressure, our results imply that if a basaltic composition was originally crystallized upon cooling during sea floor spreading, garnet granulite and/or eclogite could form via the vapor assisted diffusion mechanism at depths of $\sim 39 \pm 3 \mathrm{~km}$ at 
temperatures of $\sim 675^{\circ} \mathrm{C}$ in $\sim 10^{7} \mathrm{yr}$. Thus at greater depths the distribution of garnet will be controlled by the equilibrium phase diagram and not appreciably by reaction rates provided there are a small quantity of hydrous phases with vapor pressures similar to those of tremolite or talc. In this connection we note that the velocities of the $S_{n}$ phase propagating through the oceanic lithosphere are definitely more consistent with a partially water-bearing rock [Hart and Press, 1973]. Also, comparison of the Hart and Press [1973] results with petrological models of Forsyth and Press [1971] shows better agreement of the observed velocities with a wet peridotiteeclogite mix model than with a pure wet peridotite model lithosphere. If an appreciable gabbroic fraction exists in the $100-\mathrm{km}$-thick cooling lithosphere, we expect that increases in $P_{n}$ and $S_{n}$ velocity would reflect the gabbro-eclogite phase change predicted from the equilibrium phase diagram upon lithospheric cooling with distance from a ridge. This idea is, of course, compatible with the observation of Odegard and Sutton [1972] and Hart and Press [1973] of higher seismic velocities in the older lithosphere.

Both the formation of eclogite from the oceanic crust, which should most certainly occur at relatively shallow depth upon subduction, and the possible presence of substantial eclogite in the upper $\sim 100 \mathrm{~km}$ of the oceanic lithosphere will produce substantial downward body forces on the slab, possibly controlling the subduction process.

Acknowledgments. This research was supported by the National Science Foundation under grants GA21396 and GA10963 at C.I.T. and U.C.L.A., respectively, and by DA-ARO-D-31-124-TL-G64 at C.I.T. We have profited from discussions with A. L. Albee, C. W. Burnham, G. Ernst, D. Green, J. C. Jamieson, G. C. Kennedy, D. L. Turcotte, and M. Margretz. We thank D. E. Anderson, G. R. Buck ley, S. H. Kirby and C. B. Rayleigh for preprints of their papers. Contribution 2398, Division of Geological and Planetary Sciences, California Institute of Technology.

\section{REFERENCES}

Ahrens, T. J., Petrologic properties of the upper $670 \mathrm{~km}$ of the earth's mantle: Geophysical implications, Phys. Earth Planet. Interiors, 7, 167-186, 1973.

Allen, T. C., P. J. Modreski, C. Haggood, and A. L. Boettcher, The role of water in the mantle of the earth, The stability of amphiboles and micas, Proc. Int. Geol. Congr. 24th, Sect. 2, 231-240, 1972.

Augers, R., R. Tremblaiz, and A. C. D. Chaklader, Formation of $\mathrm{CaZrO}_{3}$ by solid-state reaction between $\mathrm{CaO}$ and $\mathrm{ZrO}_{2}, J$. Amer. Ceram. Soc., 55, 425-426, 1972.

Bett, K. E., and J. B. Cappi, Effect of pressure on the viscosity of water, Nature, 207, 620-621, 1965.

Birchenall, C. E., Diffusion in oxides: Assessment of existing data and experimental problems, in Mass Transport in Oxides, edited by J. B. Wachtman, Jr., and A. D. Franklin, Nat. Bur. Stand. Spec. Publ. 296, 119-127, 1968.

Boyd, F. R., and J. L. England, Pyrope, Carnegie Inst. Wash. Yearb., 58, 83-87, 1959.

Brace, W. F., E. Silver, K. Hadley, and C. Goetze, Cracks and pores: A closer look, Science, 178, 162-163, 1972.

Buckley, G. R., Prediction of catıon diffusion data in simple and complex oxides including silicates, submitted to Contrib. Mineral. Petrol., 1973.

Buening, D. K., and P. R. Buseck, Fe-Mg lattice diffusion in olivine, $J$. Geophys. Res., 78, 6852-6862, 1973.

Burnham, C. W., Hydrothermal fluids at the magmatic stage, in Geochemistry of Hydrothermal Ore Deposits, edited by H. L. Barnes, pp. 34-76, Holt, Rinehart, and Winston, New York, 1967.

Burte, A. S., and P. S. Nicholson, Influence of anisotropy and water vapor on the solid-state reaction of $\mathrm{CaO}$ and beta quartz, J. Amer. Ceram. Soc., 55, 472, 1972.

Champness, P. E., W. S. Fyfe, and G. W. Lorimer, Dislocations and voids in pyroxene from a low temperature eclogite: Mechanism of eclogite formation, Contrib. Mineral. Petrol., 43, 91-98, 1974.

Cohen, L. H., K. Ito, and G. C. Kennedy, Melting and phase relations in an anhydrous basalt to 40 kilobars, Amer. J. Sci., 265, 475-518, 1967.
Cooper, A. R., Jr., Model for multicomponent diffusion, Phys. Chem. Glasses, 6. 55-61, 1965.

Cutler, I. B., Effect of water vapor on the sintering of glass powder compacts, J. Amer. Ceram. Soc., 52, 11-13, 1969.

Davis, R. F., and J. A. Park, Diffusion and reaction studies in the system $\mathrm{Al}_{2} \mathrm{O}_{3}-\mathrm{SiO}_{2}$, J. Amer. Ceram. Soc., 55, 525-531, 1972.

Dudley, P. P., Electron microprobe analyses of garnet in glaucophane schists and associated eclogites, Amer. Mineral., 54, 1139-1150, 1969.

Dudziak, K. H., and E. V. Franck, Messungen der Viskosttät des Wassers bis $560^{\circ} \mathrm{C}$ and 3500 bar, Ber. Bunsenges. Phys. Chem., 70. $1120-1128,1966$.

Essene, E. J., B. J. Hensen, and D. H. Green, Experimental study of amphibolite and eclogite stability, Phys. Earth Planet. Interiors, 3, 378-384, 1970.

Evans, B. W., and V. Trommsdorf, Regional metamorphoses of ultramafic rocks in the central Alps: Paragenesis in the system $\mathrm{CaO}$ $\mathrm{MgO}-\mathrm{SiO}_{2}-\mathrm{H}_{2} \mathrm{O}$, Schweiz. Mineral. Petrogr. Mitt., 50, 481-492, 1970.

Evans, B. W., and V. Trommsdorf, Dereinfluss des Eisens auf die Hydratisierung von Duniten, Schweiz. Mineral. Petrogr. Mitt., 52, 251-256, 1972.

Forsyth, D. W., and F. Press, Geophysical tests of petrological models of the spreading lithosphere, J. Geophys. Res., 76, 7963-7979, 1971.

Froidevaux, C., and G. Schubert, Plate motion and structure of the continental asthenosphere: A realistic model of the upper mantle, J. Geophys. Res., 80, in press, 1975.

Fry, N., and W. S. Fyfe, Eclogites and water pressure, Contrib. Mineral. Petrol., 24, 1-6, 1969.

Fyfe, W. S., and J. Verhoogen, Kinetics of metamorphic reactions, in Metamorphic Reactions and Metamorphic Facies, edited by W. S. Fyfe, F. J. Turner, and J. Verhoogen, Geol. Soc. Amer. Mem., 73, 53-103, 1958.

Garrels, R. M., and C. L. Christ, Solutions, Minerals, and Equilibria, pp. 96, 421, 100-106, Harper and Row, New York, 1965.

Giardini, A. A., V. J. Hurst, C. E. Melton, and J. C. Stormer, Jr., Biotite as a primary inclusion in diamond: Its nature and significance, Amer. Mineral., 59, 783, 1974.

Graham, E. K., and T. J. Ahrens, Shock compression of iron-silicate garnet, J. Geophys. Res., 78, 375-392, 1973

Green, D. H., and A. E. Ringwood, An experimental investigation of the gabbro to eclogite transformation and its petrological applications, Geochim. Cosmochim. Acta, 31, 767-834, 1967.

Green, D. H., and A. E. Ringwood, A comparison of recent experimental data on the gabbro-garnet granulite-eclogite transition, J. Geol., 80, 277-288, 1972.

Green, H. W., II, A $\mathrm{CO}_{2}$ charged asthenosphere, Nature Phys. Sci., $238,1-4,1972$.

Greenwood, H. J., The system NaAlSi $\mathrm{O}_{6}-\mathrm{H}_{2} \mathrm{O}$-argon: Total pressure in metamorphism, J. Geophys. Res., 66, 3923-3946, 1961.

Greenwood, H. J., The synthesis and stability of onthophyllite, $J$. Petrol., 4, 317-351, 1963.

Griggs, D. T., The sinking lithosphere and the focal mechanism of deep earthquakes, in The Nature of the Solid Earth, edited by E. C. Robertson, pp. 361-384, McGraw-Hill, New York, 1972.

Hamann, S. D., and M. Linton, Electrical conductivity of water in shock compression, Trans. Faraday Soc., 62, 2234-2241, 1966.

Hart, R. S., and F. Press, $S_{n}$ velocities and the composition of the lithosphere in the regionalized Atlantic, J. Geophys. Res., 78, 407-411, 1973.

Helgeson, H. C., and D. H. Kirkham, Theoretical prediction of the thermodynamic behavior of aqueous electrolytes at high pressures and temperatures, 1, Summary of the thermodynamic-electrostatic properties of the solvent, Amer. J. Sci., 274(10), 1089, 1974.

Heuer, A. H., A. R. Cooper, and R. Barnard, Oxygen diffusion in forsterite, paper presented at the Carnegie Conference on Geochemical Transport and Carnegie Inst. Washington, Airlie House, Warrenton, Va., June 4-6, 1973.

Hill, R. E., and A. L. Boettcher, Water in the earth's mantle: Melting curves of basalt-water and basalt-water-carbon dioxide, Science, 167, 980-982, 1970.

Holloway, J. R., and C. W. Burnham, Melting relations of basalt with equilibrium water pressure less than total pressure, J. Petrol., 13, I-29, 1972.

Iseki, T., K. Yamaguchi, and A. Tagai, Solid-state reaction between $\mathrm{SrO}$ and $\mathrm{BaO}$ and single-crystal $\mathrm{Al}_{2} \mathrm{O}_{3}$, J. Amer. Ceram. Soc., 53, $425,1970$.

Ito, K., Petrological models of the oceanic lithosphere: Geophysical and geochemical tests, Earth Planet. Sci. Lett., 21, 169-180, 1974. 
Ito, K., and G. C. Kennedy, The fine structure of the basalt-eclogite transition, Mineral. Soc. Amer. Spec. Pap. 3, 77-83, 1970.

Ito, K., and G. C. Kennedy, An experimental study of the basalt-garnet granulite-eclogite transition, in The Structure and Physical Properties of the Earth's Crust, edited by J. G. Heacock, Geophys. Monogr. Ser., vol. 14, pp. 303-314, AGU, Washington, D. C., 1971.

Jost, W., Diffusion in Solids, Liquids, Gases, Academic, New York, 1960.

Kennedy, G. C., Pressure-volume-temperature relations in water at elevated temperatures and pressures, Amer. J. Sci., 248. 540-564, 1950.

Kennedy, G. C., The origin of continents, mountain ranges, and ocean basins, Amer. Sci., 47, 491-504, 1959.

Kennedy, G. C., and W. T. Holser, Pressure-volume-temperature and phase relations of water and carbon dioxide, in Handbook of Physical Constants, rev. ed., edited by S. P. Clark, Jr., Geol. Soc. Amer. Mem., 97, 371-384, 1966.

Kennedy, G. C., and K. Ito, Comments on 'A comparison of recent experimental data on the gabbro-garnet granulite-eclogite transition,' J. Geol., 80, 289-292, 1972.

Kennedy, G. C., and R. N. Keeler, Compressibility, in American Institute of Physics Handbook, 3rd ed., edited by D. E. Gray, pp. 438-4-104, McGraw-Hill, New York, 1972.

Kennedy, G. C., G. J. Wasserburg, H. C. Heard, and R. C. Newton, The upper three-phase region in the system $\mathrm{SiO}_{2}-\mathrm{H}_{2} \mathrm{O}$, Amer. J. Sci., 260. 501-521, 1962.

Kern, R., and A. Weisbrod, Thermodynamics for Geologists, p. 141, Freeman Cooper, San Francisco, Calif., 1967.

Kestin, J., and R. Dipippo, Viscosity of gases, in American Institute of Physics Handbook, 3rd ed., edited by D. E. Gray, pp. 2-232-2-248, McGraw-Hill, New York, 1972.

King, E. G., R. Barang, W. W. Weller, and L. B. Paukratz, Thermodynamic properties of forsterite and serpentine, U.S. Bur. Mines Rep. Invest. 6962, 1967.

Kitahara, S., S. Takanouchi, and G. C. Kennedy, Phase relations in the system $\mathrm{MgO}-\mathrm{SiO}_{2}-\mathrm{H}_{2} \mathrm{O}$ at high temperatures and pressures, A mer. J. Sci., 264, 223-233, 1966.

Kumer, V., and Y. P. Gupta, Cation self-difusion in single crystal $\mathrm{CaO}, J$. Phys. Chem., 30, 677-685, 1969.

Kushiro, I., Y. Syona, and S. Akimoto, Stability of phlogopite at high pressures and possible presence of phlogopite in earth's upper mantle, Earth Planet. Sci. Lett., 3, 197-203, 1967.

Lindner, R., Studies on solid state reactions with radiotracers, $J$. Chem. Phys., 23, 410-411, 1955.

Lindner, R., and A. Akerström, Diffusion von Ni-63 in Nickelspinellen, Z. Phys. Chem. Neue Folge, 18, 303-307, 1958.

Longworth, L. G., Diffusion in liquids, in American Institute of Physics Handbook, 3rd ed., edited by D. E. Gray, pp. 2-221-2-227, McGraw-Hill, New York, 1972.

Lovering, J. F., The Nature of the Mohorovicic discontinuity, Eos Trans. AGU, 39, 947-955, 1958.

McGetchin, T. R., L. T. Silver, and A. A. Chodos, Titanoclinohumite: A possible mineralogical site for water in the upper mantle, $J$. Geophys. Res., 75, 255-259, 1970.

McGregor, I. D., The reaction 4 enstatite + spinel $=$ forsterite + pyrope, Carnegie Inst. Wash. Yearb., 63, 157, 1964.

McKenzie, D. P., Speculations on the consequences and causes of plate motions, Geophys. J. Roy. Astron. Soc., 18, 1-32, 1969.

Meisner, D. J., Cationic diffusion in olivine to $1400^{\circ} \mathrm{C}$ and $35 \mathrm{~kb}$, in Geochemical Transport and Kinetics, edited by A. W. Hoffman, B. J. Gillette, H. S. Yoder, Jr., and R. A. Lund, Carnegie Inst. Washington Publ. 634, 117-130, 1974.

Mistler, R. E., and R. L. Coble, Rate determining species in diffusioncontrolled processes in $\mathrm{Al}_{2} \mathrm{O}_{3}, J$. Amer. Ceram. Soc., 54, 60-61, 1971.

Modreski, P. J., and A. L. Boettcher, Phase relations of phlogopite in the system $\mathrm{K}_{2} \mathrm{O}-\mathrm{MgO}-\mathrm{CaO}-\mathrm{Al}_{2} \mathrm{O}_{3}-\mathrm{SiO}_{2}-\mathrm{H}_{2} \mathrm{O}$ to 35 kilobars: $\mathrm{A}$ better model for micas in the interior of the earth, Amer. J. Sci., 273, $383-414,1973$.

Morey, G. W., The solubility of solids in gases, Econ. Geol., 52, 225-251, 1957.

Morey, G. W., and J. M. Hesselgesser, The solubility of some minerals in superheated steam at high pressures, Econ. Geol., 46, 821-835, 1951.

Mukherjee, J. L., and F. F. Y. W.ang, Kinetics of solid-state reactions of $\mathrm{Bi}_{2} \mathrm{O}_{3}$ and $\mathrm{Fe}_{2} \mathrm{O}_{3}$, J. Amer. Ceram. Soc., 54, 31-34, 1970.
Mysen, B. O., and A. L. Boettcher, Phase relations in peridotite- $\mathrm{H}_{2} \mathrm{O}-$ $\mathrm{CO}_{2}$ systems with controlled $\mathrm{H}_{2} \mathrm{O}$ and $f_{\mathrm{O}_{2}}$, Eos Trans. $A G U, 54$, $480,1973$.

Nagashima, A., and $I$. Tanishita, Viscosity measurements of water and steam at high temperatures and high pressures, Bull. JSME, 12, 1467-1478, 1969.

Odegard, M. E., and G. H. Sutton, The Cannikin airborne seismic experiment, Geol. Soc. Amer. Progr. Abstr., 4, 212, 1972.

Oxburgh, E. R., Petrological evidence for the presence of amphibole in the upper mantle and its petrogenetic and geophysical implications, Geol. Mag., 101, 1-19, 1964.

Paladino, A. E., and R. L. Coble, Effect of grain boundaries on diffusion-controlled processes in aluminum oxide, J. Amer. Ceram. Soc., 46, 133-136, 1963.

Paladino, A. E., and W. D. Kingery, Aluminum ion diffusion in aluminum oxide, J. Chem. Phys., 37, 957-962, 1962.

Poldervaart, A., Chemistry of the earth's crust, Geol. Soc. Amer. Spec. Pap. 62, 119-144, 1955.

Press, F., The suboceanic mantle, Science, 165, 174-176, 1969.

Rice, M. H., and J. M. Walsh, Equation of state of matter to 250 kilobars, J. Chem. Phys., 26, 824-830, 1957.

Ringwood, A. E., and D. H. Green, An experimentad investigation of the gabbro-eclogite transformation and some geophysical implications, Tectonophysics, 3, 383-427, 1966.

Robie, R. A., and D. R. Waldbaum, Thermodynamic properties of minerals and related substances at $298.15^{\circ} \mathrm{K}\left(25^{\circ} \mathrm{C}\right)$ and one atmosphere (1.013 bars) pressure and at higher temperatures, $U . S$. Geol. Surv. Bull., 1259, 1968.

Ronov, A. B., and A. A. Yaroshevsky, Chemical composition of the earth's crust, in The Earth's Crust and Upper Mantle, edited by P. J. Hart, Geophys. Monogr. Ser., vol. 13, pp. 37-57, AGU, Washington, D. C., 1969.

Schmalzreid, H., Chemical reactions between crystallirie solids, in Reactivity of Solids, edited by J. W. Mitchell, R. C. DeVries, R. W. Roberts, and P. Cannon, pp. 551-566, John Wiley, New York, 1969.

Schubert, G., and D. L. Turcotte, Phase changes and mantle convection, J. Geophys. Res., 76, 1424-1432, 1971.

Schubert, G., and D. L. Turcotte, Basalt-eclogite phase transition in the descending crust, Eos Trans. AGU, 53, 521, 1972.

Schubert, G., D. A. Yuen, and D. L. Turcotte, Role of phase changes in a dynamic mantle, Geophys. J. Roy. Astron. Soc., in press, 1974.

Shettel, D. L., Jr., Solubility of quartz in $\mathrm{H}_{2} \mathrm{O}-\mathrm{CO}_{2}$ fluids at $5 \mathrm{~kb}$ and $500^{\circ}-900^{\circ} \mathrm{C}$, Eos Trans. AGU, 54, 480, 1973.

Spry, A., Metamorphic Textures, pp. 104-108, 153, Pergamon, New York, 1969

Taylor, H. P., and R. G. Coleman, $\mathrm{O}^{18} / \mathrm{O}^{18}$ ratios of coexisting minerals in glaucophane-bearing metamorphic rocks, Bull. Geol. Soc. Amer., 79, 1727-1757, 1968.

Toksöz, M. N., J. W. Minear, and B. R. Julian, Temperature field and geophysical effects of a downgoing slab, J. Geophys. Res., 76, 1113-1138, 1971.

Turcotte, D. L., and E. R. Oxburgh, Convection in a mantle with variable physical properties, J. Geophys. Res., 74, 1458-1474, 1969.

Turcotte, D. L., and G. Schubert, Structure of olivine-spinel phase boundary in the descending lithosphere, J. Geophys. Res., 76, 7980-7987, 1971.

Turcotte, D. L., and G. Schubert, Frictional heating of the descending lithosphere, J. Geophys. Res., 78, 5876-5886, 1973.

Vinogradov, A. P., The formation of the ocean, Izv. Akad. Nauk SSSR Ser. Geol., 4, 3-9, 1967.

Walton, M., Molecular diffusion rates in supercritical $\mathrm{H}_{2} \mathrm{O}$ vapor estimated from viscosity data, Amer. J. Sci., 258, 385-401, 1960.

Wuensch, B. J., and T. Vasilos, Impurity cation diffusion in magnesium oxide, Nat. Bur. Stand. Spec. Publ. 296, 95-112, 1968.

Wyllie, P. J., Ultramafic rocks and the upper mantle, Mineral. Soc. Amer. Spec. Pap. 3, 3, 1970.

Wyllie, P. J., The Dynamic Earth: Textbook in Geosciences, pp. 63-90, John Wiley, New York, 1971.

Yoder, H. S., Jr., The role of water in metamorphism, The Crust of the Earth, Geol. Soc. Amer. Spec. Pap. 62, 505-524, 1955.

Yoder, H. S., Jr., and C. E, Tilley, Origin of basalt magma: An experimental study of natural and synthetic rock systems, J. Petrol., 3, $342-352,1962$.

(Received October 11, 1973; accepted October 12, 1974.) 